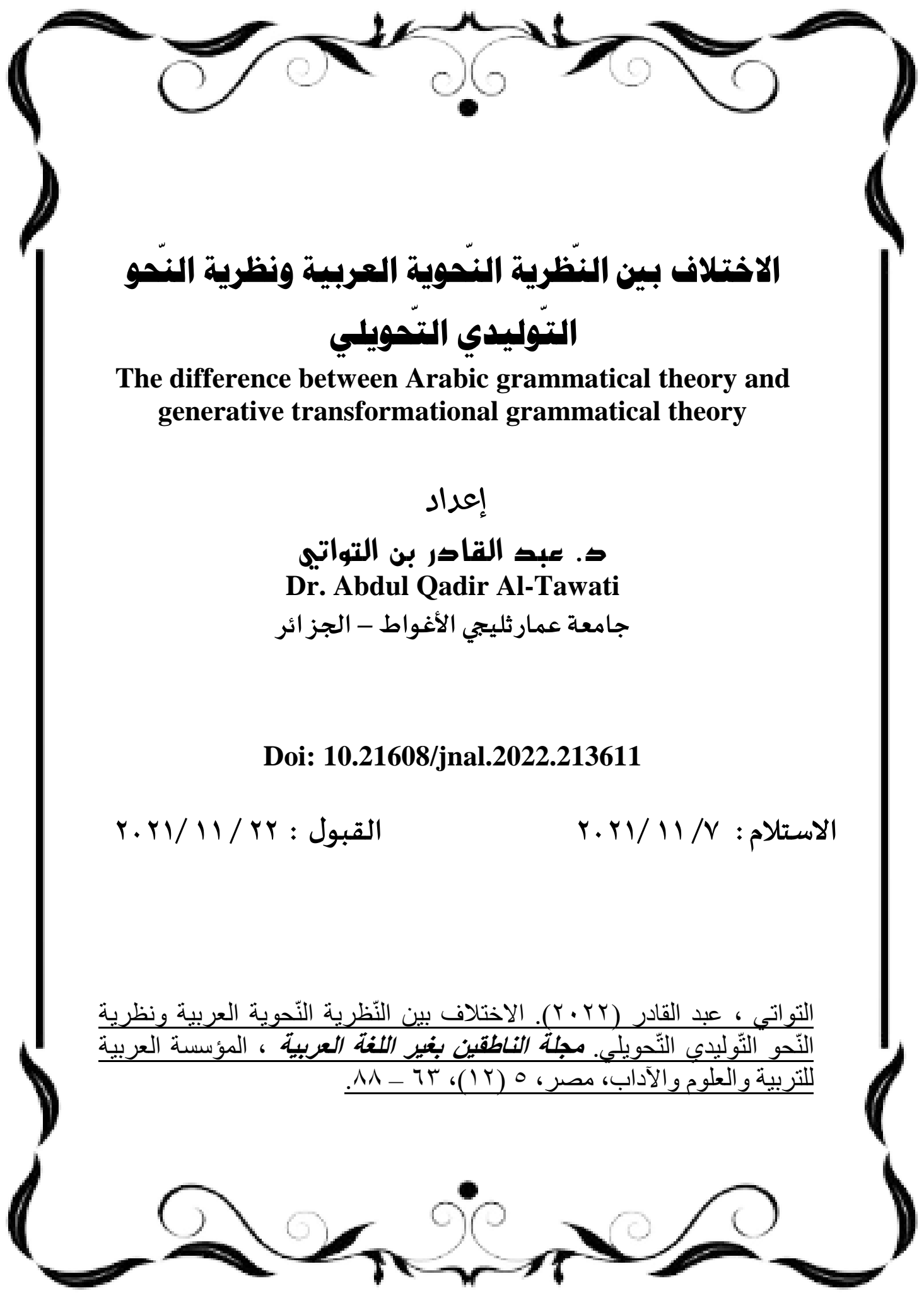




\section{الاختلاف بين النّظرية النّحوية العربية ونظرية النّحو التّوليدي التّحويلي}

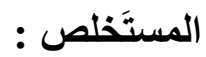

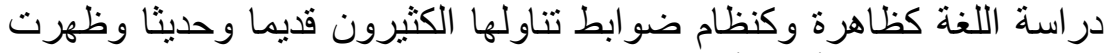

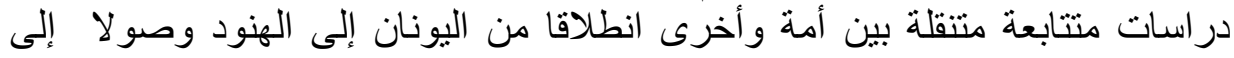

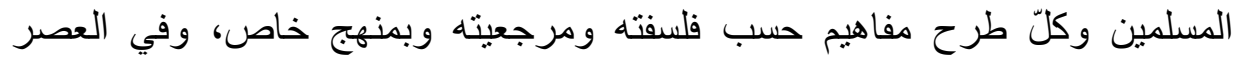

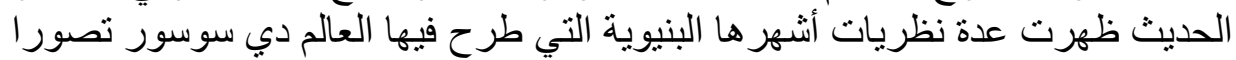

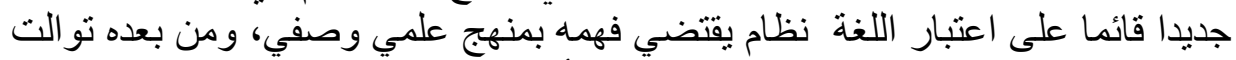

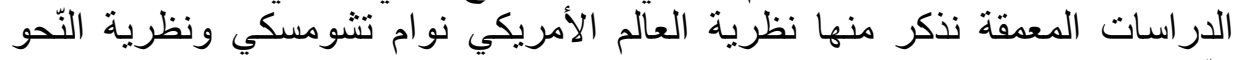

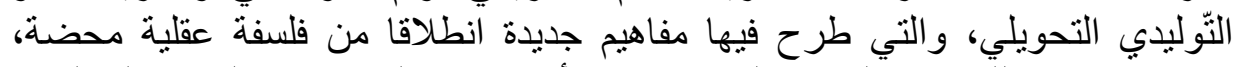

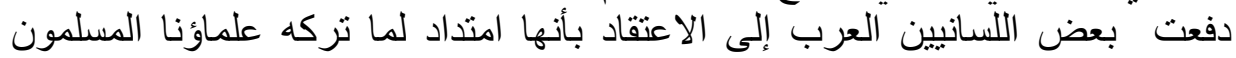

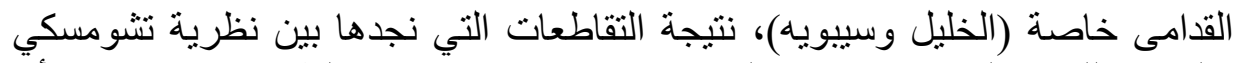

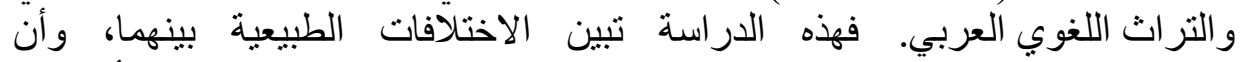

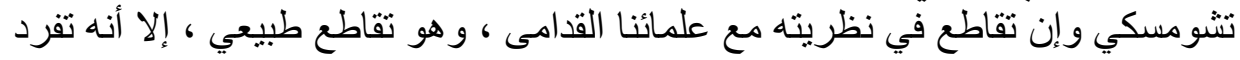

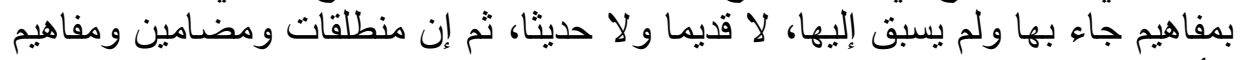

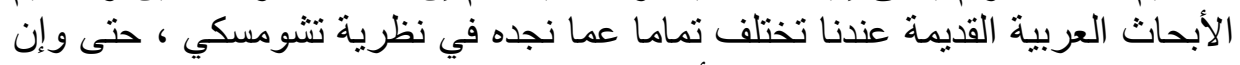

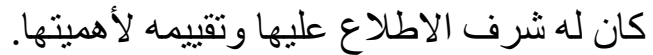
الكلمات المفتاحية: اللغة_ المنطلقات الاخيمه لاهتلافات. ـالتقاطعات

\section{Abstract:}

The study of language as a phenomenon and as a system of controls dealt with by many, in the past and in the present, and there have been successive studies moving between one nation and another, starting from Greece to the Indians to the Muslims. Considering language as a system that requires understanding it with a descriptive scientific method, and after that, in-depth studies followed, including the theory of the American scientist Noam Chomsky and the theory of transformational generative grammar, in which he put forward new concepts based on a purely rational philosophy. It led some Arab linguists to believe that it is an extension of what our ancient Muslim scholars left, especially (Hebron and Sibawayh), as a result of the intersections that we find between Chomsky's theory and the Arabic linguistic heritage. This study shows the natural differences between them, and that 
Chomsky, even if he intersects in his theory with our ancient scholars, and it is a natural intersection, but he singled out concepts that he brought and did not precede them, neither ancient nor modern. Moreover, the premises, contents and concepts of the ancient Arabic researches we have are completely different from what we find in Chomsky's theory, even if he had the privilege of reading it and evaluating its importance.

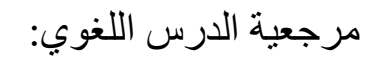
أ-النظرية النحوية الخليلية.

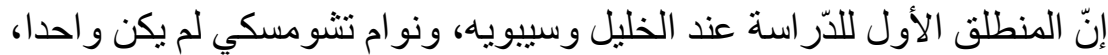

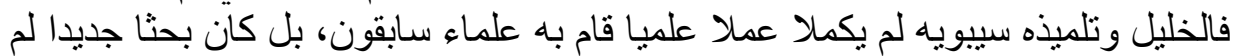

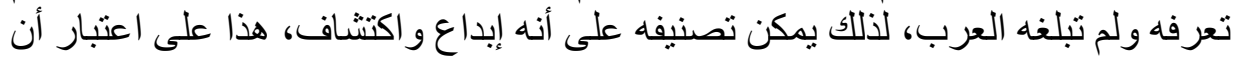

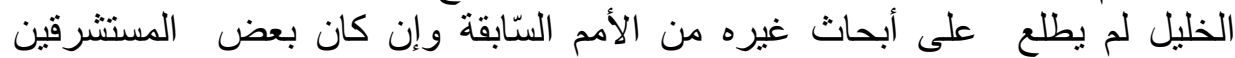

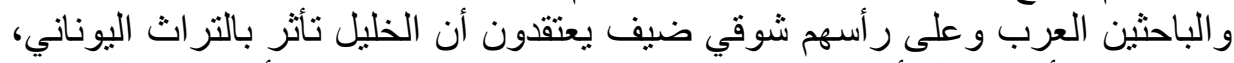

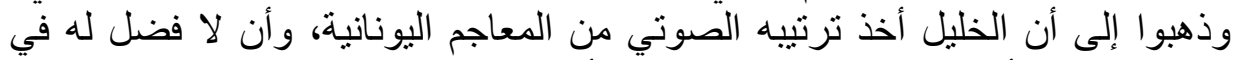

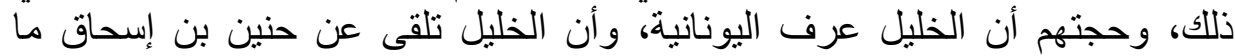

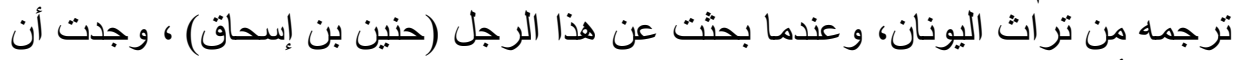

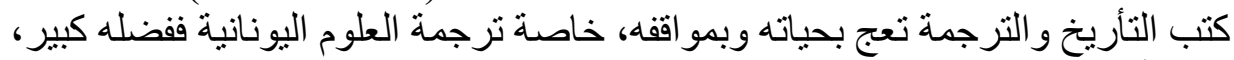

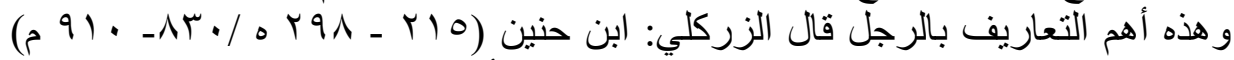

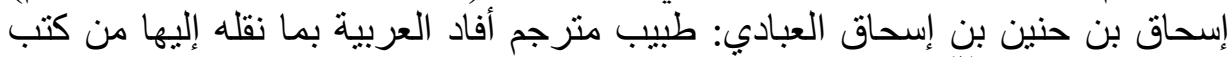

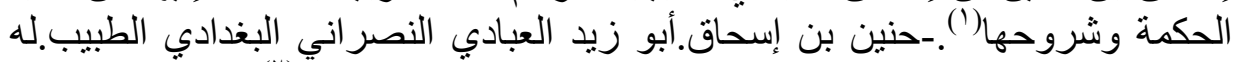

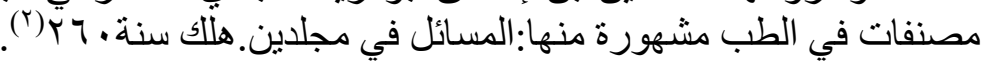

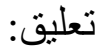

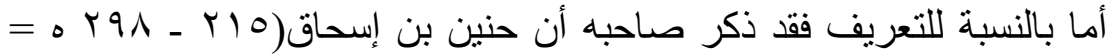

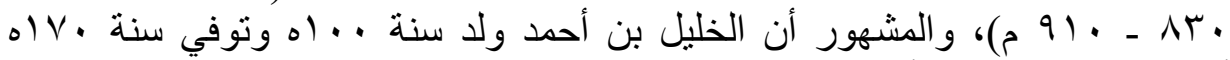

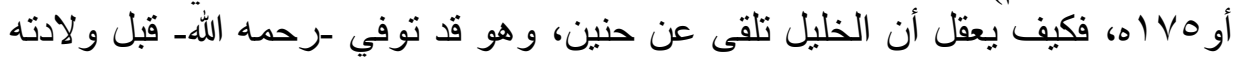

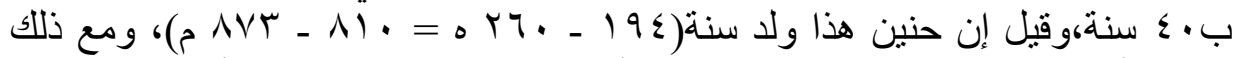

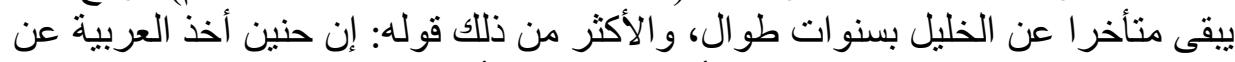
الخليل،و هذا غير مقبول للسبب نفسه أيضا.فالملاحظ أن الخليل لا علاقة اله له بهذا الرجل الرجل

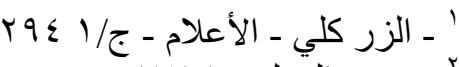

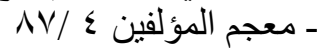


إطلاقا، وقد يكون حنين أفاد من تراث الخليل بعد وفاته، عن طريق تلامذته..لأن هذا

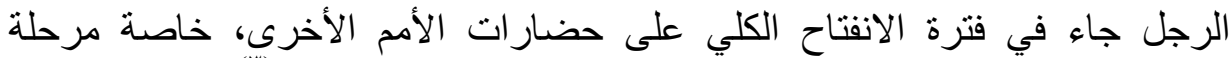

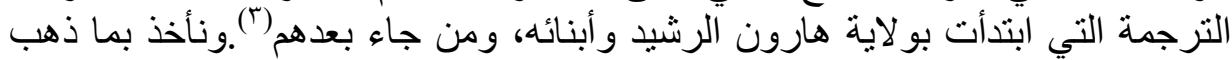

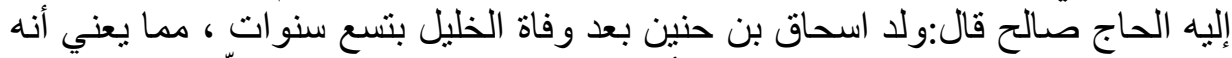

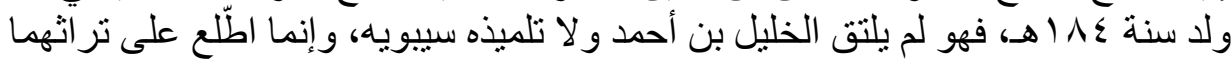

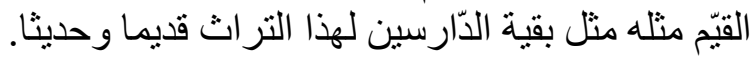

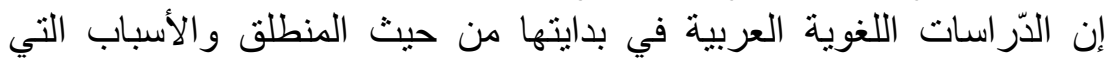

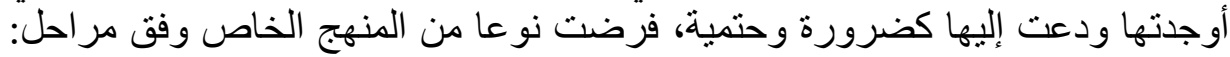

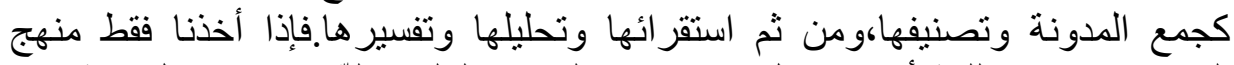

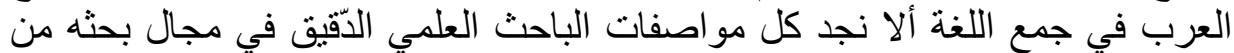

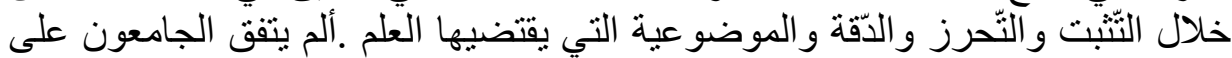

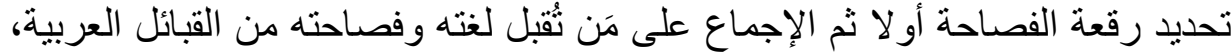

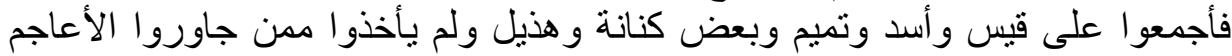

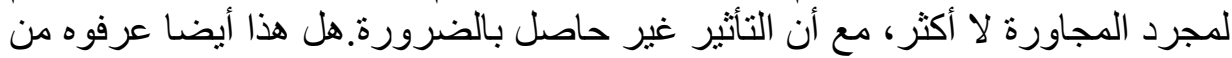

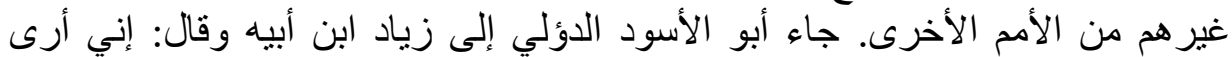

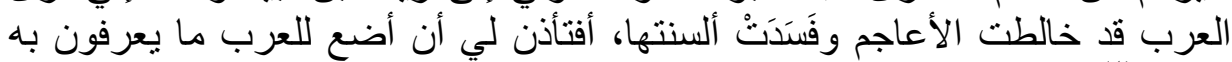

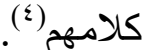

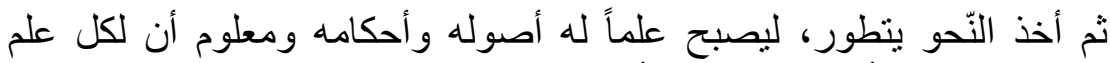
مصطلحات هي بمثابة أوعينة ، فمن أين استمد العربي وهو ابن الصحراء الهراء هذه

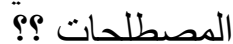

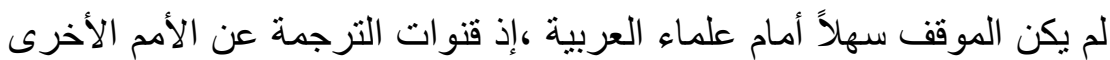

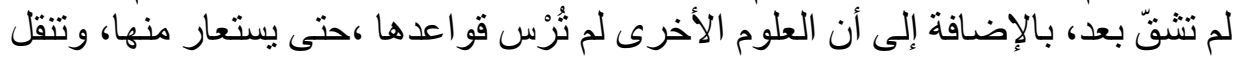

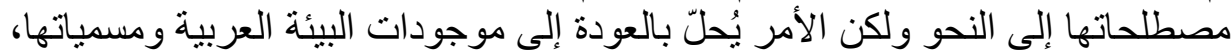

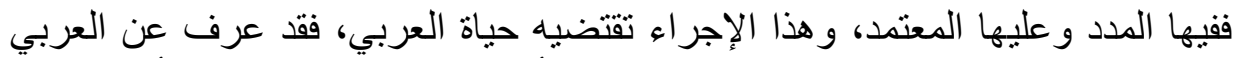

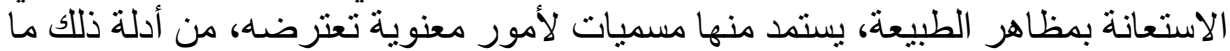

'ــــ والنص بشبر إلى ذلك: واتصل بالمأمون فجعله رئيسا لديوان الترجمة، وبذل له الأموال

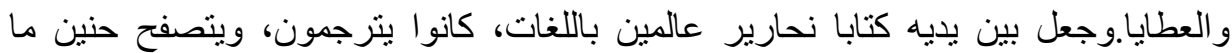

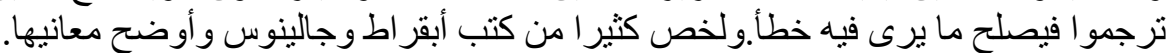

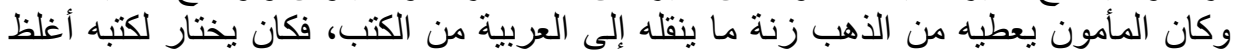

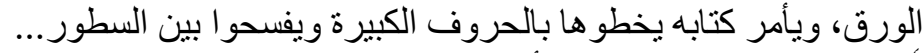

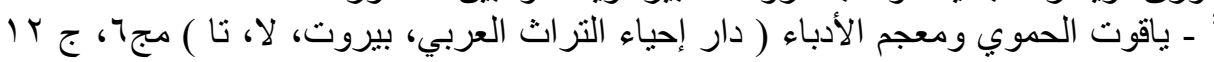




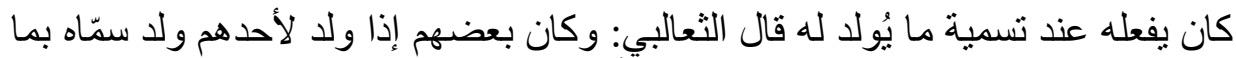

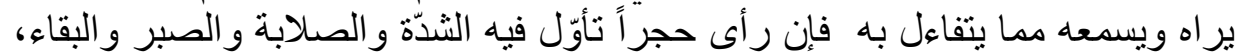

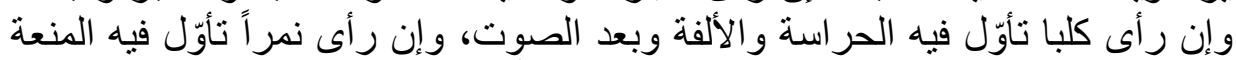

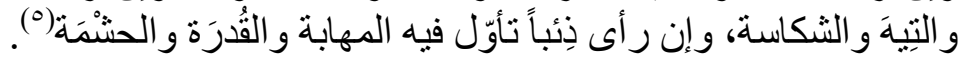

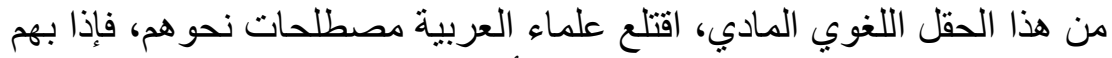

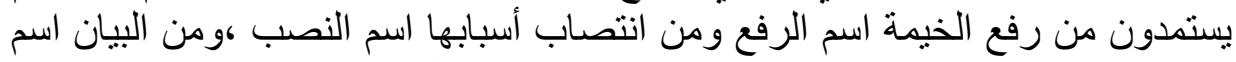

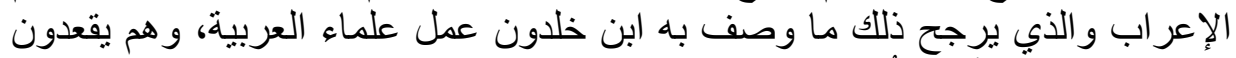

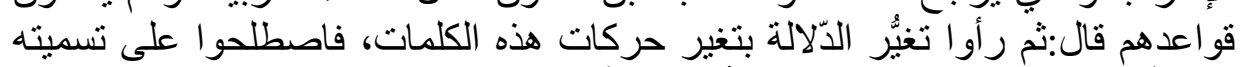

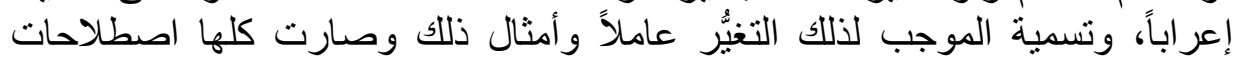

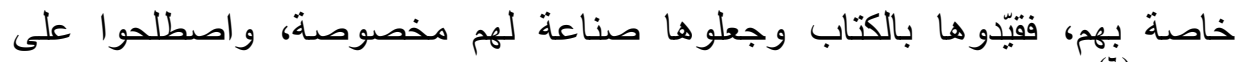

تسميتها تخاصة

ب-نظرية النحو التوليدي التحويلي.

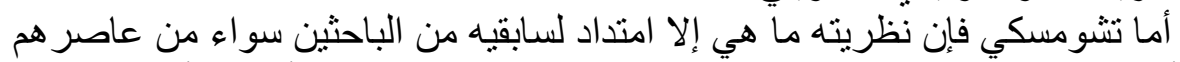

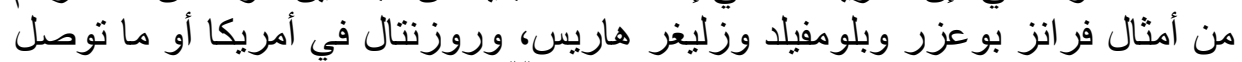

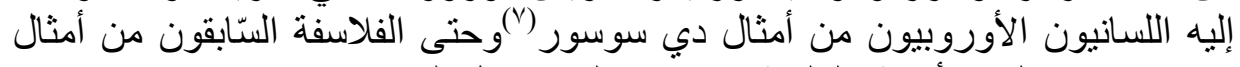

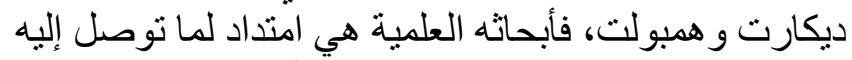

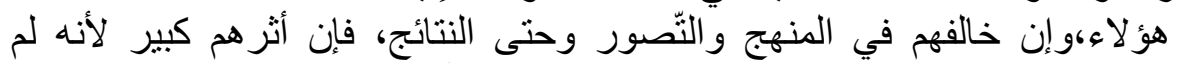

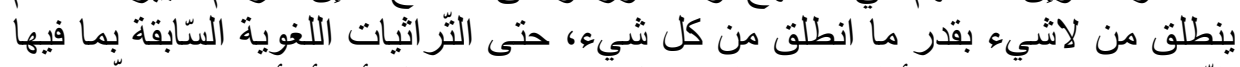

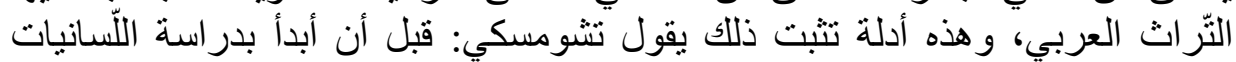

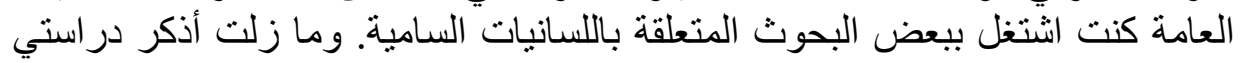

• ـ الثعالبي : فقه اللغة وأسرار العربية ( منشورات دار مكتبة الحياة، بيروت، لا، تا ) ص

r $r \leqslant 1-r \leqslant$.

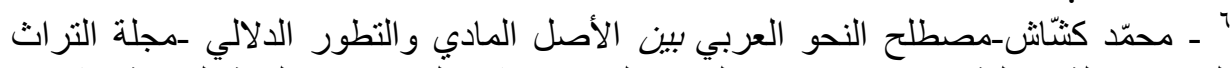

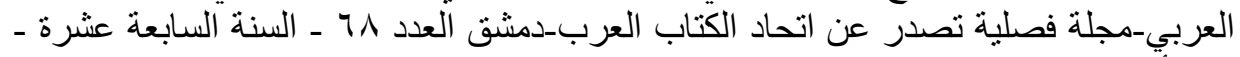

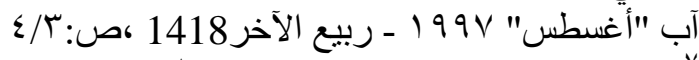

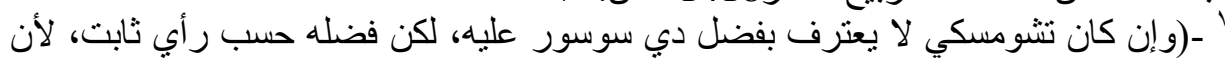

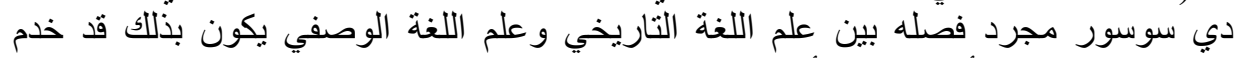

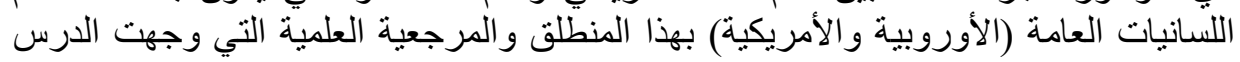

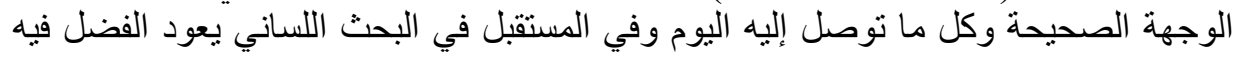




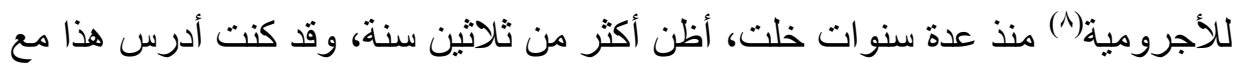

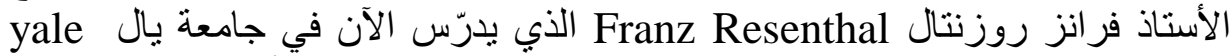

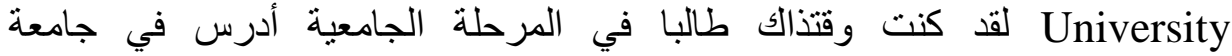

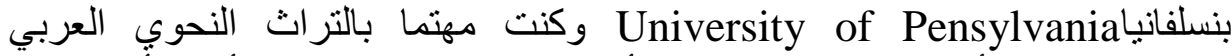

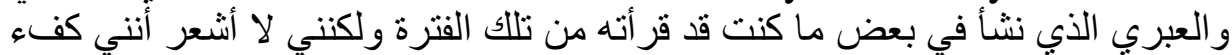

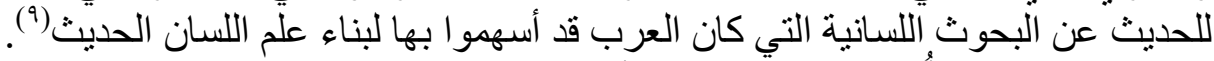

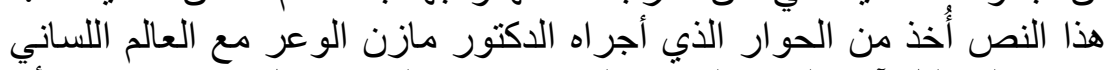

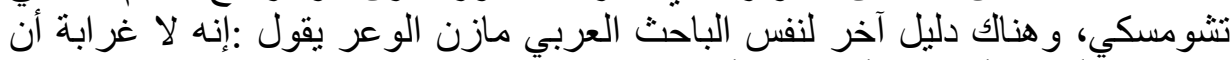

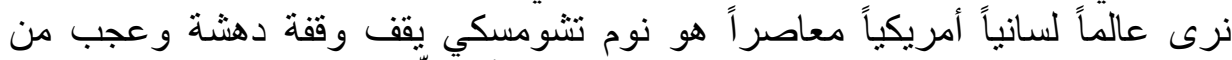

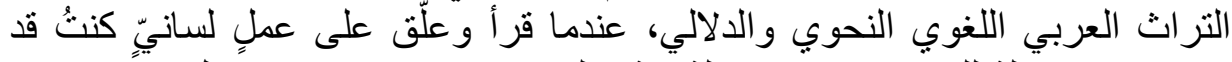

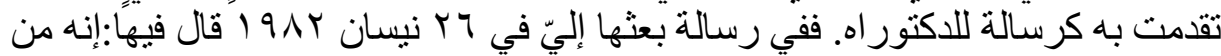

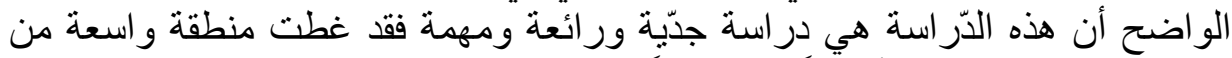

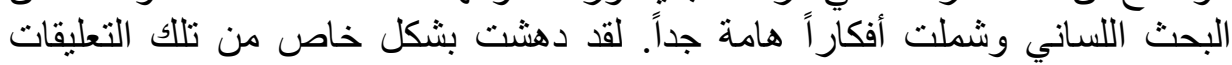

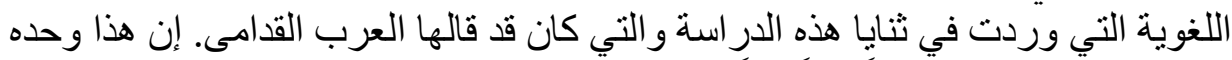

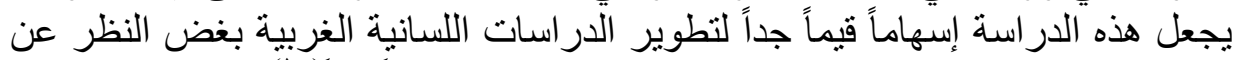

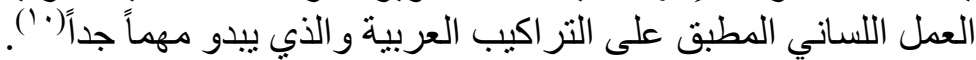

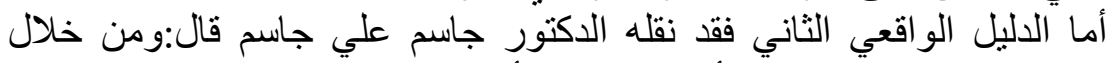

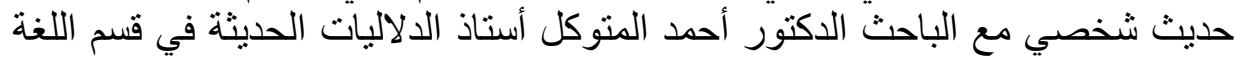

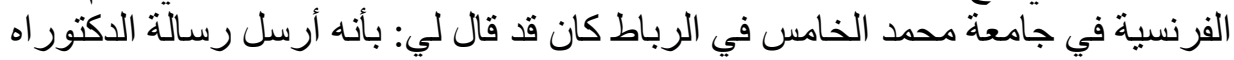
التي وضعها والتي تدور حول النظرية الدلالية عند العرب القدان لقدائ إلى إلى عالم اللسانيات

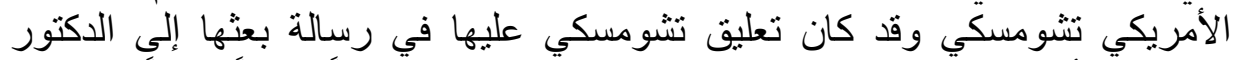

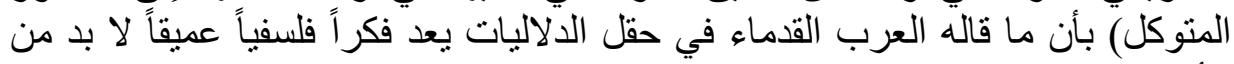

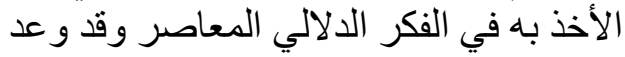

^ ـالأجرومية:هو كتاب مختصر مشهور في النحو العربي لمؤلفه ابن آجروم(القرن الثامن

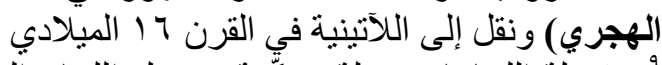

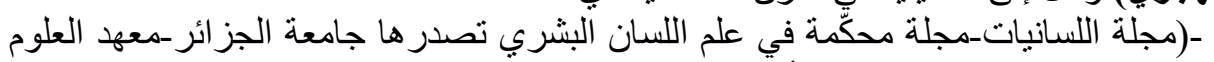

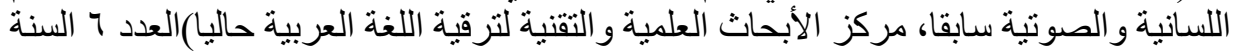
VY:ص 19AY ـ ـضايا أساسية في علم اللسانيات الحديث مدخل: الوعر، مازن- دمثقـ- دار طلاس

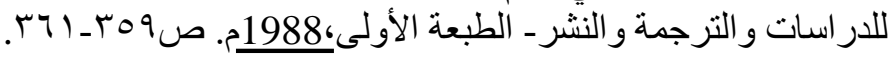


تشومسكي المتوكل بأنه سيعتمد هذه النظرية في الأعمال التي سيقوم بها في المستقبل (1) - (1) - (1).

ومن هنا يجب أن نعترف بأن النظرية التوليدية التحويلية هي وليدة عدة تراثات

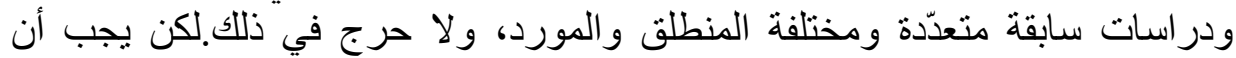

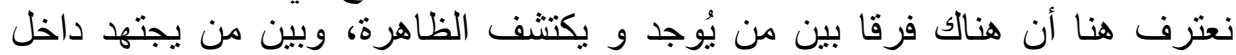

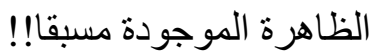

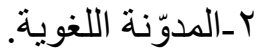
أ_النظرية النحوية الخليلية. إن الحديث عن المدوّنة اللغوية العربية يجرّنا إلى الحديث عن جمعها أولا، ثم الحكم عرفنا أن سبب جمع اللغة ودر استها بمنهج علمي استقر ائي رياضي كان بسبب عليها. انتشار اللحن في الألسن الناطقة للغة القرآن الكريم لذلك فكروا في تقعيدها، ودئ وكانت عملية الجمع وفق منهج تشدّد فيه الجامعون على درجة التضييق في رقعة الفصاحة حتى فئى

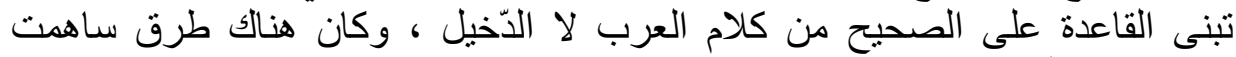
لامحالة في تأكيد غايتهم العلمية. إن أوّل علاقية بين اللغوبين والبدو في في ديار هم كانت في القرن الثاني، و لا

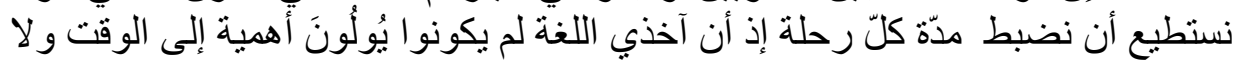

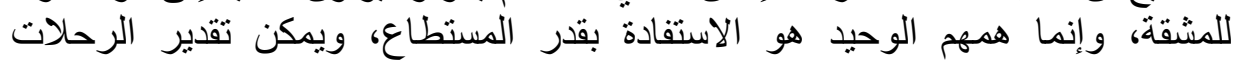

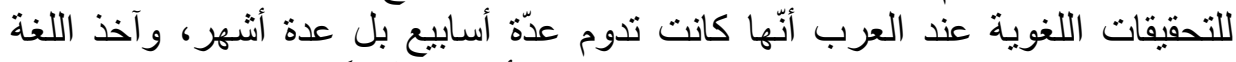

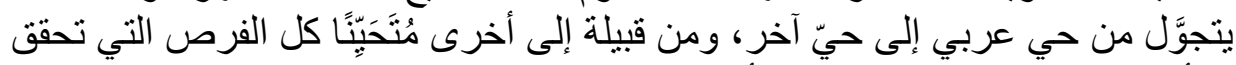

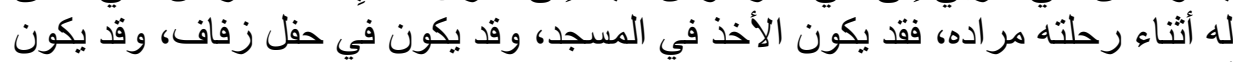

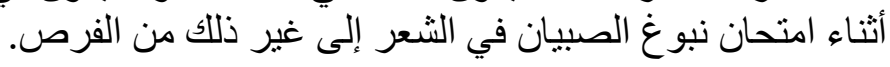

- جاسم علي جاسم -تأثنير النحو العربي في نظرية تشومسكي - معهد تعليم اللغة العربية

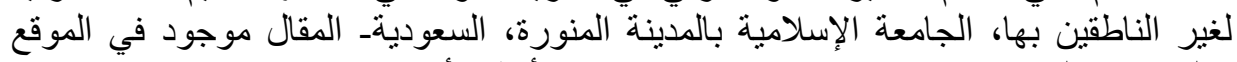

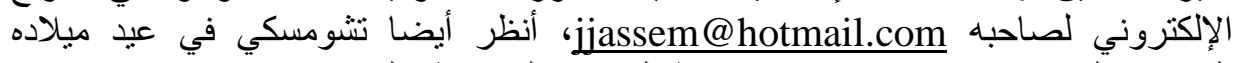

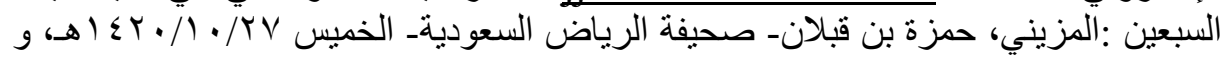

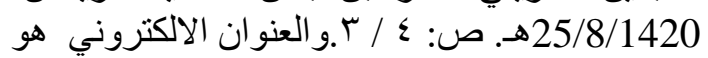

http://www.hmozainy.jeeran.com/tshomesky4.htm http://www.hmozainy.jeeran.com/tshomesky2.htm ص: (ص: 
فإذا أخذنا الوسائل المستعملة في الأسفار تحقق لدينا أن الرحلة كانت تدوم مدة

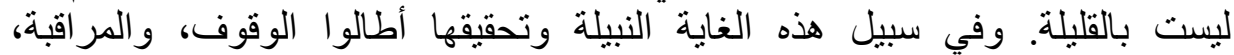

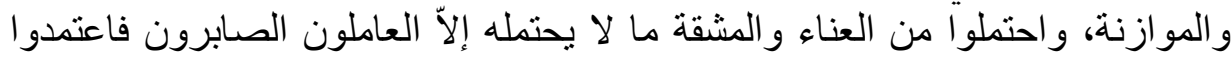

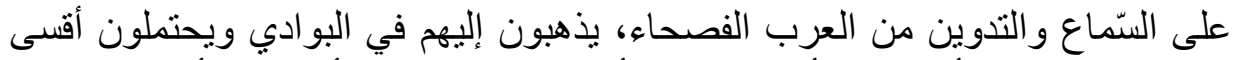

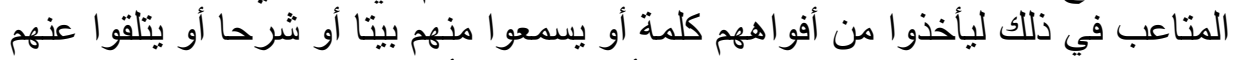

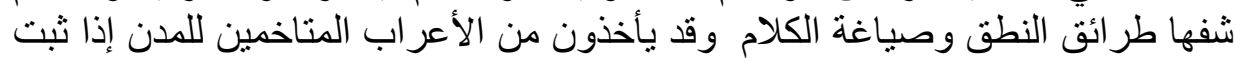

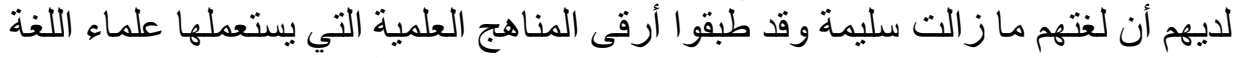

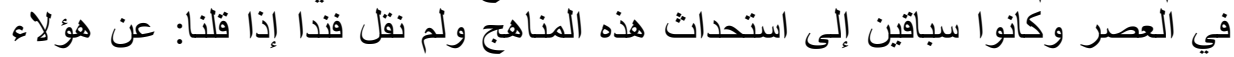
أخذّت المناهج العلمية في ميدان علم المئ اللغة.

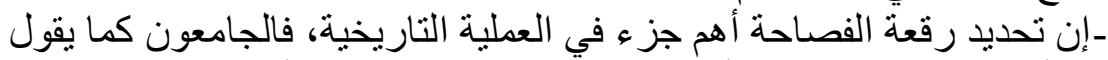

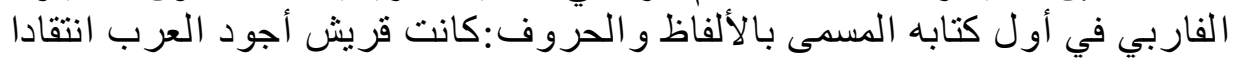

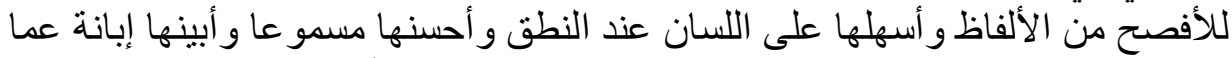

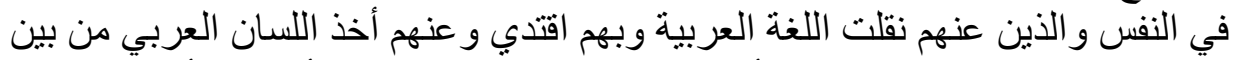

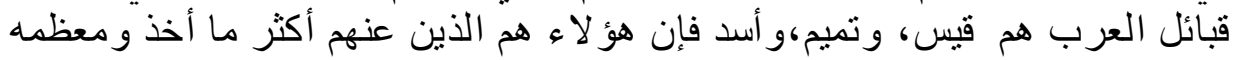

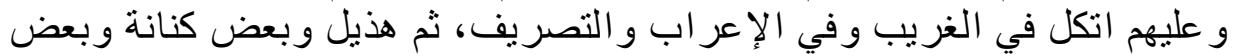

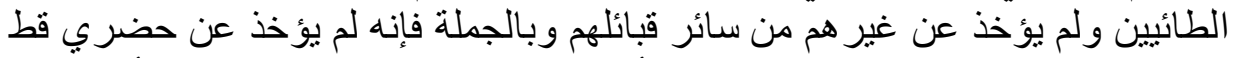

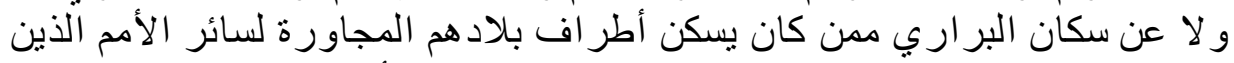

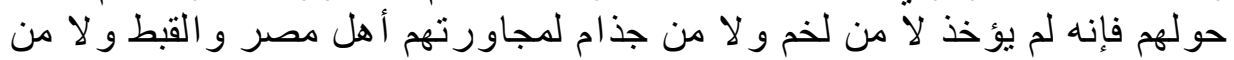

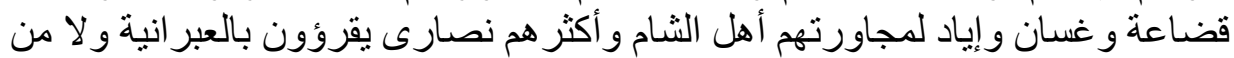

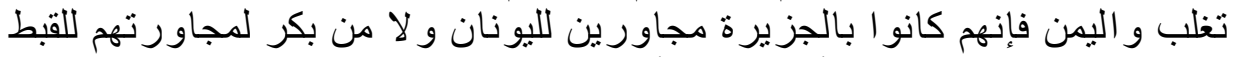

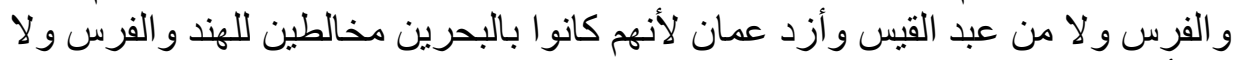

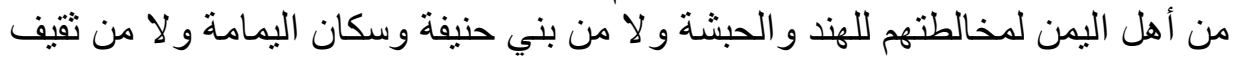

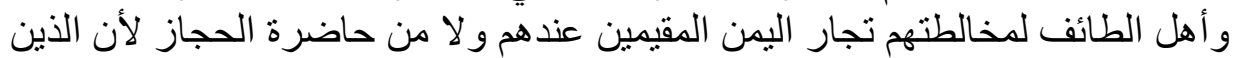

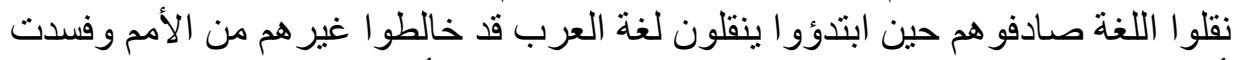

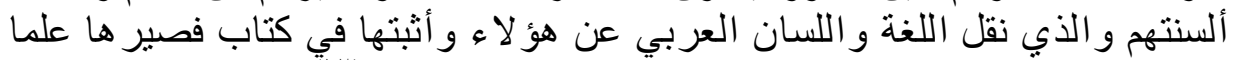

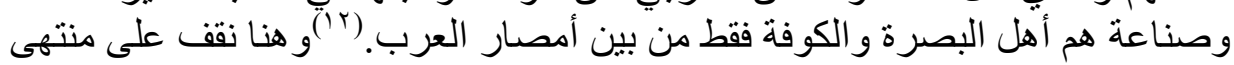
الدّقة العلمية والتّتبت للوصول التهرة إلى ما يثلج الصدر.

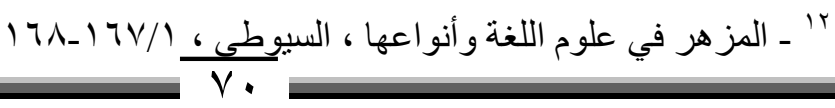




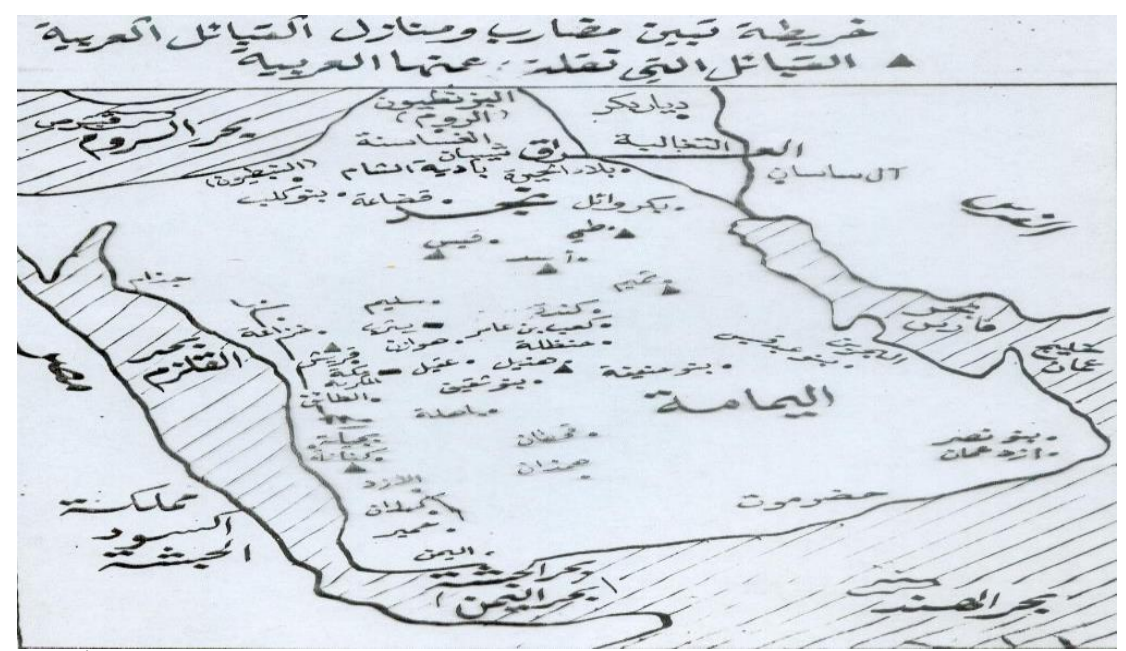

(الخريطة تبيّن مضارب ومنازل القبائل العربية لشبه الجزيرة وهي مأخوذة من

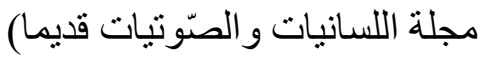

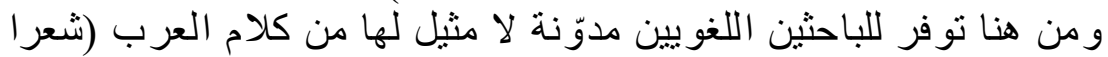

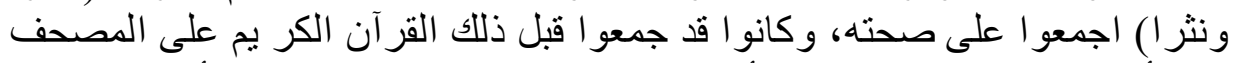

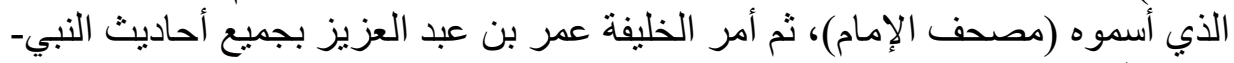

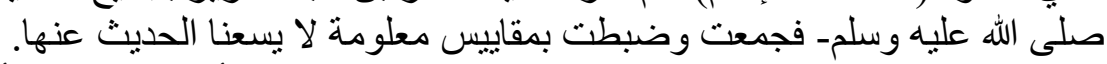

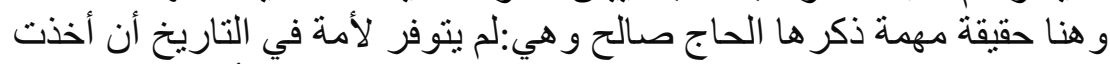

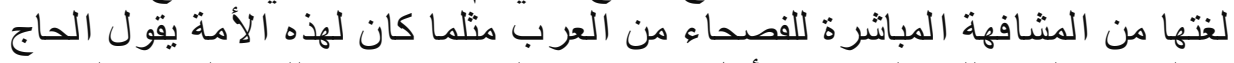

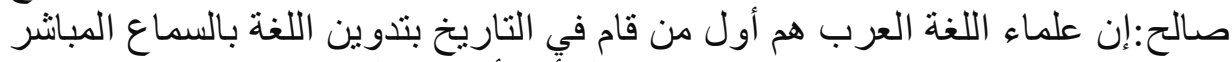

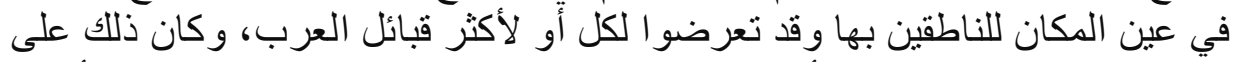

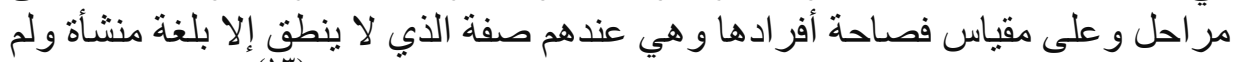

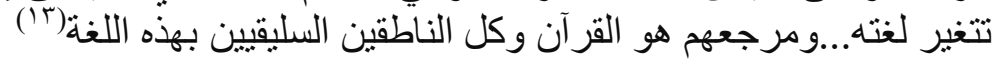

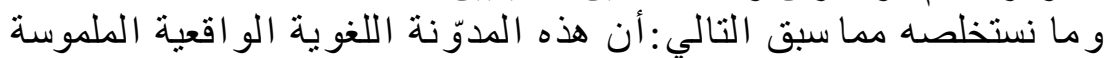

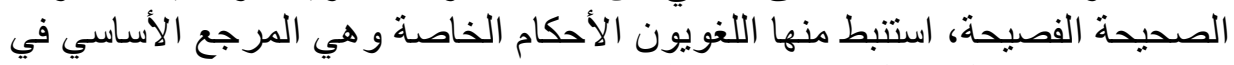
عمليات القياس وكل مجال من مجالات التقعيد الإنساني و العلمي. ب-نظرية النحو التوليدي التحويلي.

كا" ـ عبد الرحمان الحاج صالح - السماع اللغوي العلمي عند العرب ومفهوم الفصاحة.، $\overline{V_{1}}$ ص:الأخيرة 
أما اللغة عند تثومسكي فهي واقع آخر مخالف تماما لما رأيناه في الدراسات

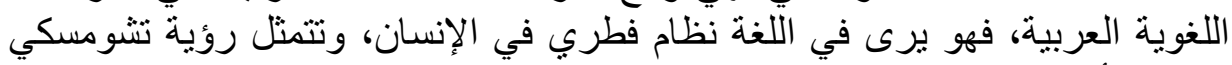

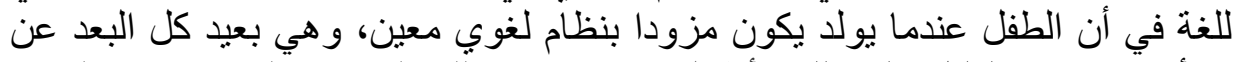

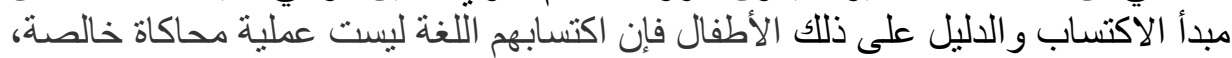

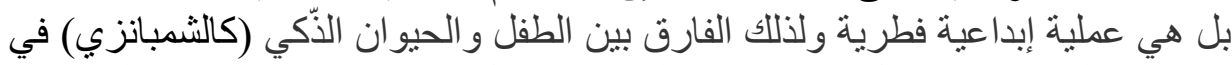

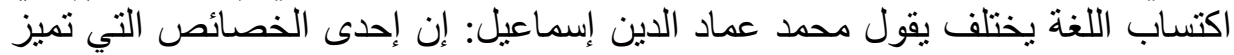

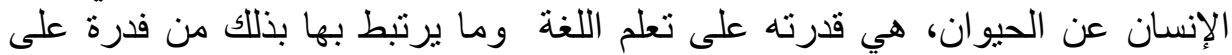

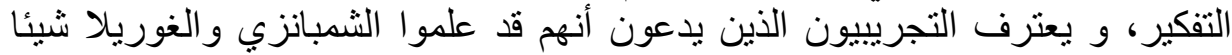

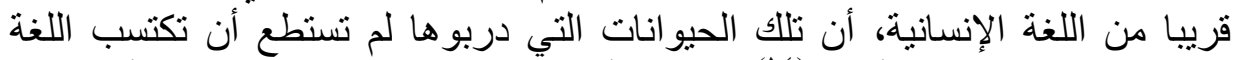

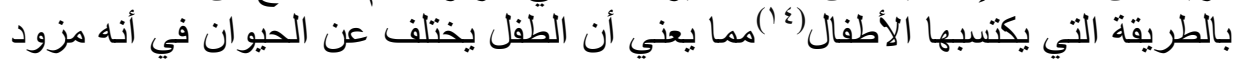

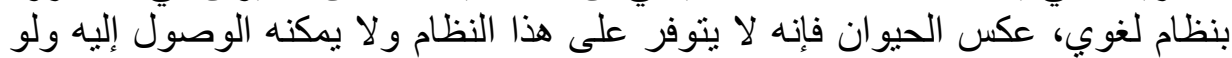

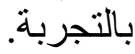

ومن هذا المنطلق برزت نظرية التثومسكي التي تتحدث عن فطرية اللغة، في

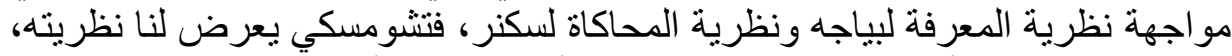

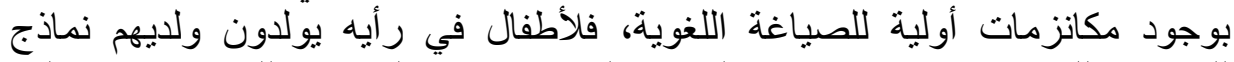

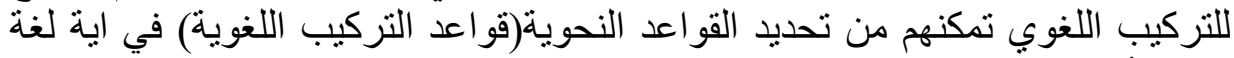

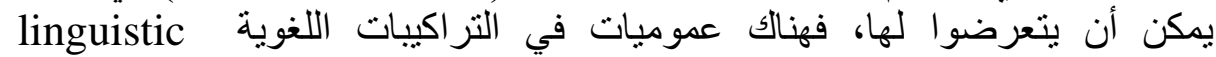
universals

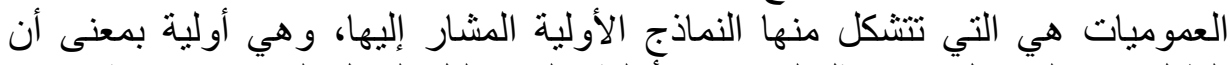

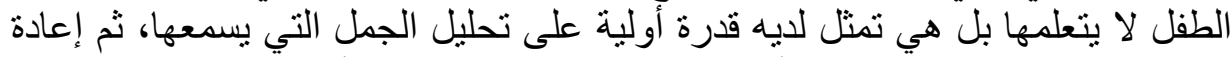

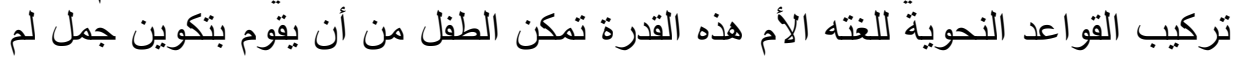

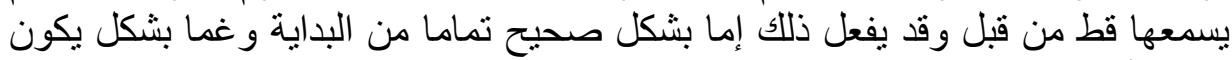
على الأقل مفهوما ومقبو لا من ناحية الآخرين(10)،

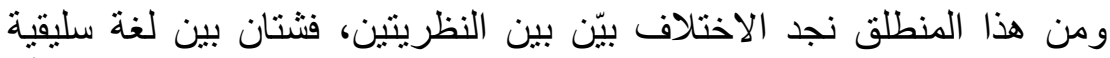

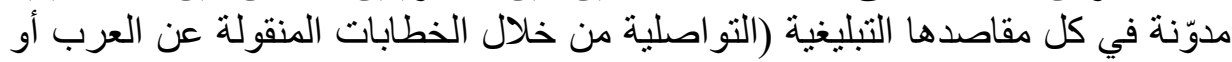

؛' ـ ـ محمد عماد الدين إسماعيل ـالأطفال مر آة المجتمع- علم المعرفة سلسلة كتب ثقافية شهرية

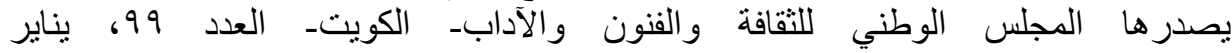

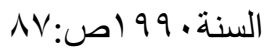
10 ـ ـ محمد عماد الدين إسماعيل ـالأطفال مر آة المجتمع- علم المعرفة سلسلة كتب ثقافية شهرية

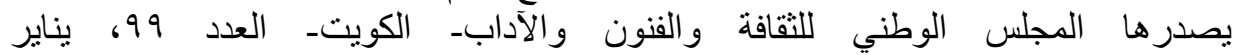

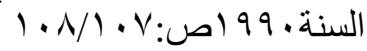




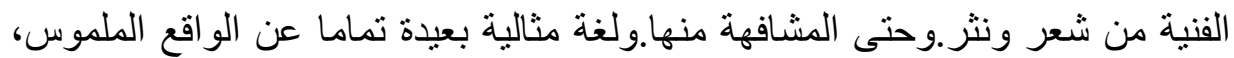

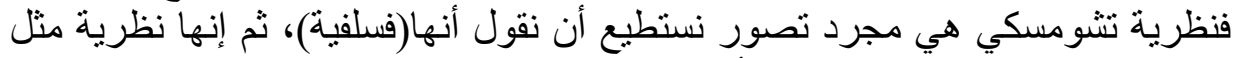

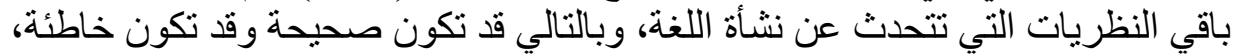
والحقيقة أن نظرية المحاكاة أكثر و اقعية منها.

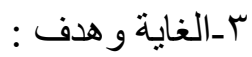

أـالنظرية النحوية الخليلية.

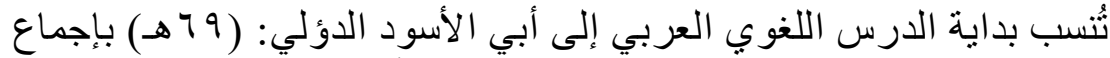

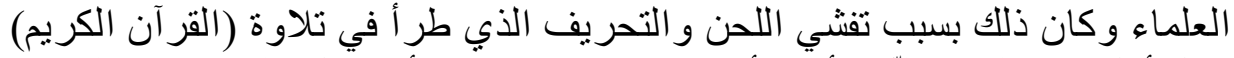

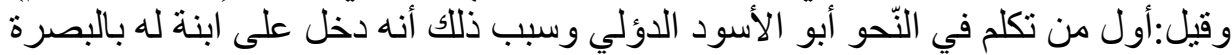

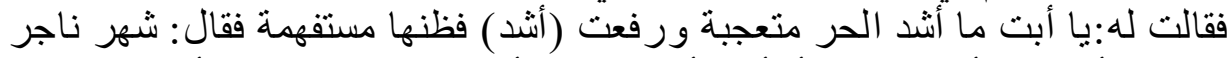

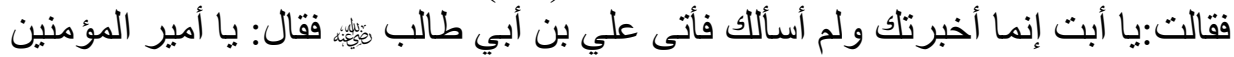

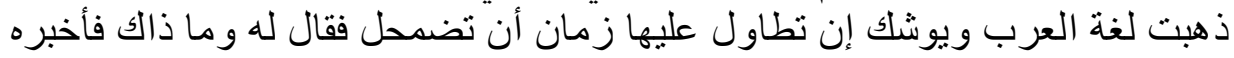

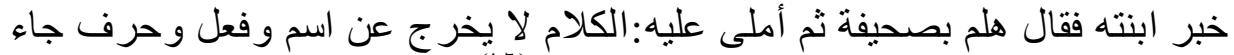

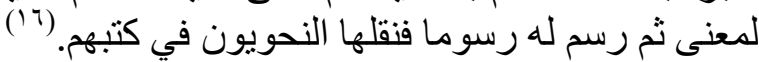

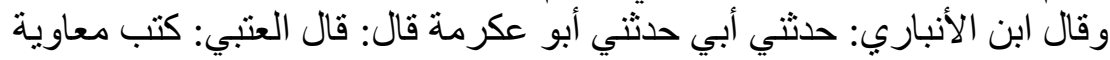

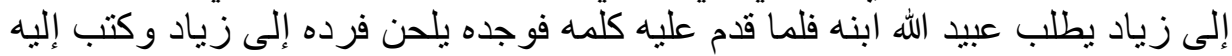

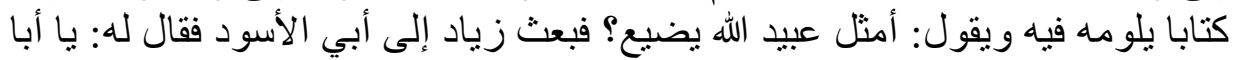

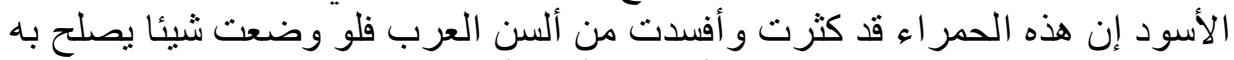

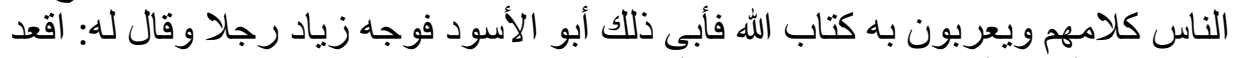

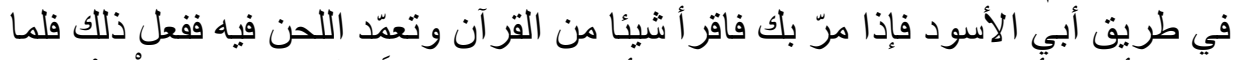

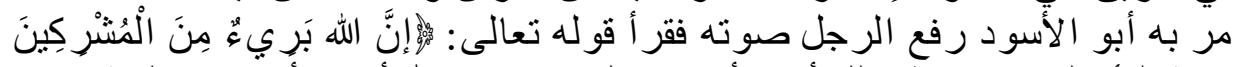

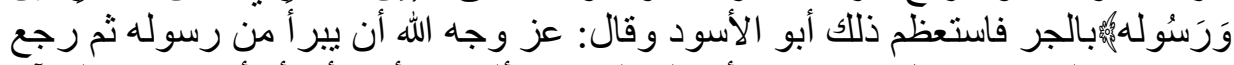

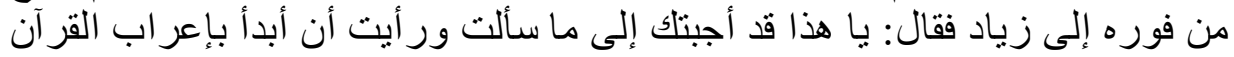

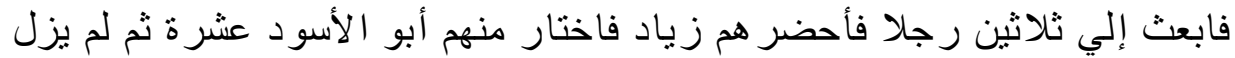

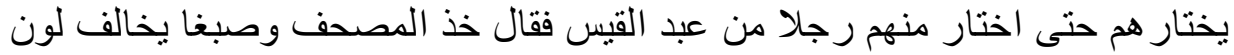

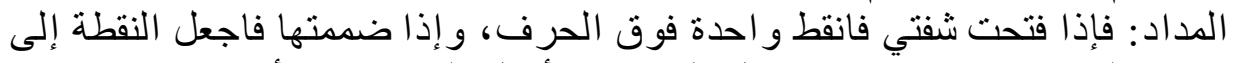

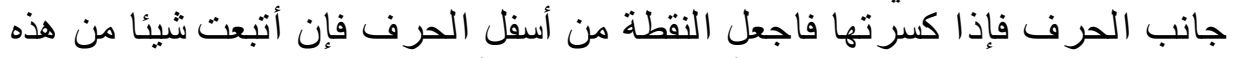

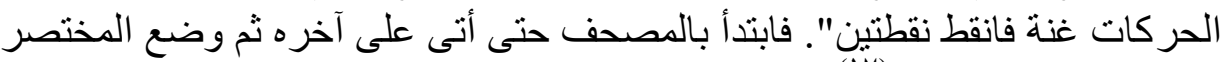

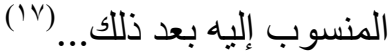

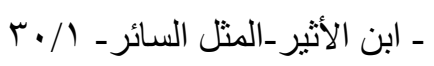

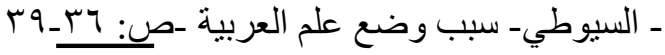




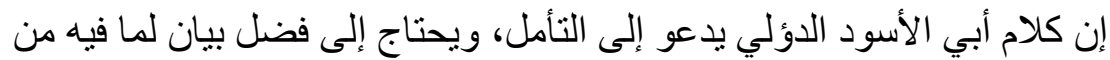

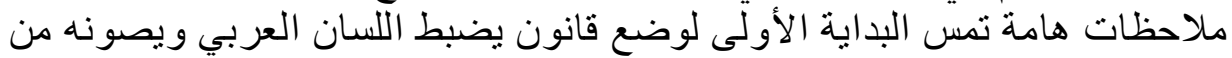

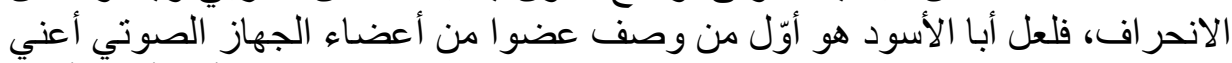

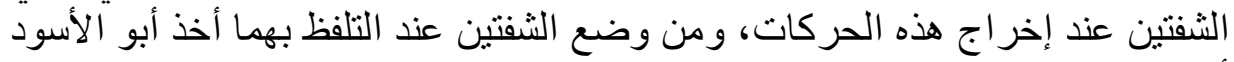

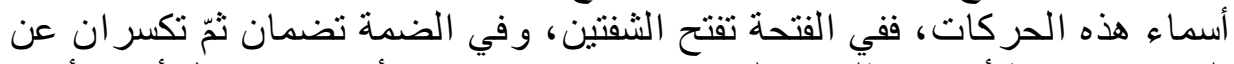

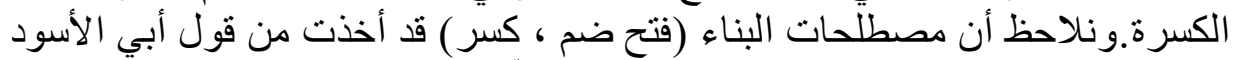

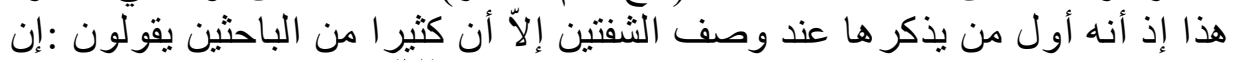

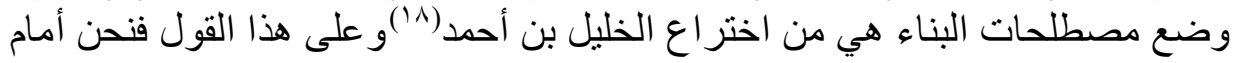
(أ) إما أن تكون ألقاب من اختر اع الخليل بن أحمد، ولكنه نظر في قول أبي

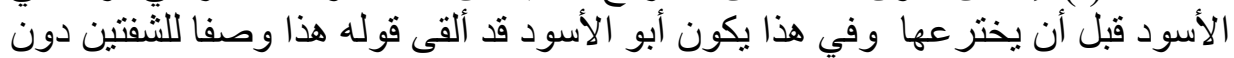
قصد منه إلى تعيين حركات ألبناء. (ب)-و إما أن يكون أبو الأسود هو الذي اختر عها عند وصف وضع الثفقتين

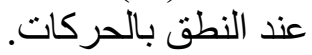
و المرجح هو الاحتمال الأول إذ أن أبا الأسود بلئه لم يكن يفكر في وضع مصطلحات

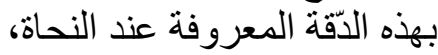

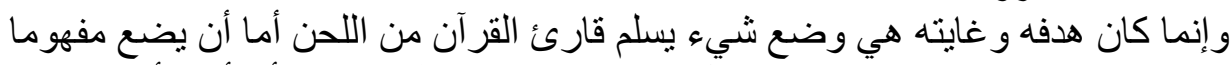

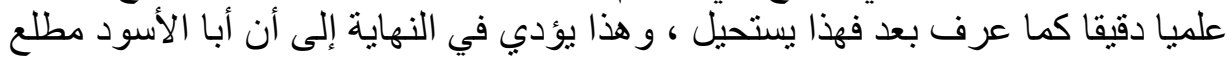

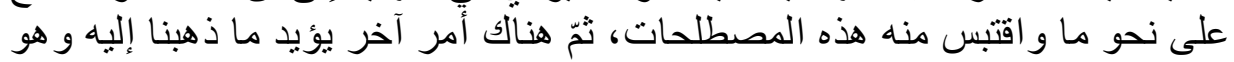

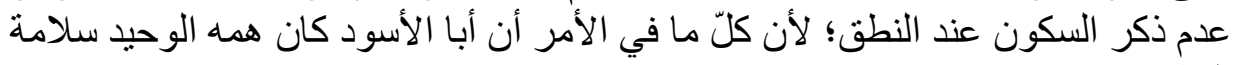

وما يهمنا في هذا المقام، هو ما نخلص إليه لمعرفة الغاية و الهدف من الدراسات

النطق.

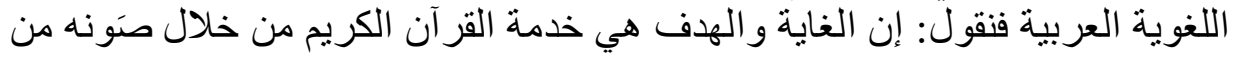

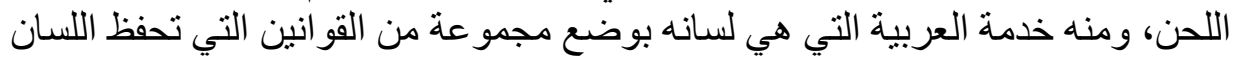

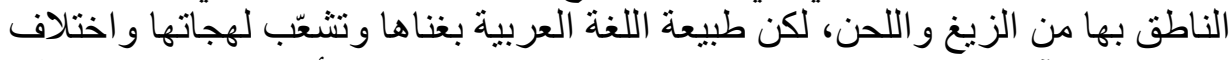

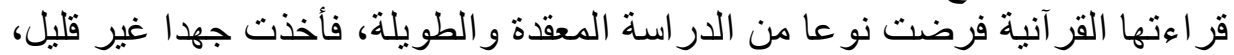
وتجاوزت في زمانها أجيالا وأجيال وماز الت التبالت تبتغي المزيد. ب-نظرية النحو التوليدي التحويلي. أما نظرية تنومسكي فهي عكس الدراسات العربية تبغي ألتئي أكثر من ذلك، فهي

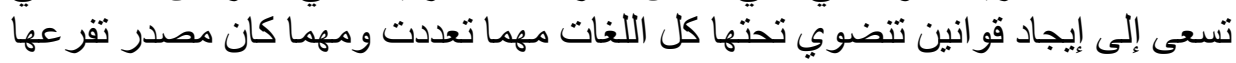

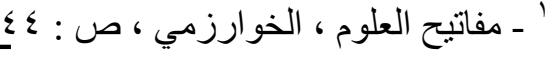


يقول الدكتور إبراهيم كونغ الجو :إن هدف المدرسة التوليدية التحويلية الأساسي هو

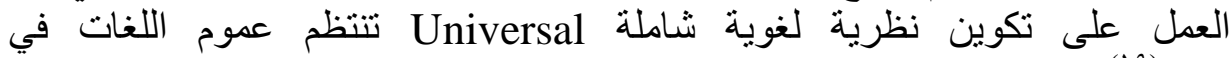

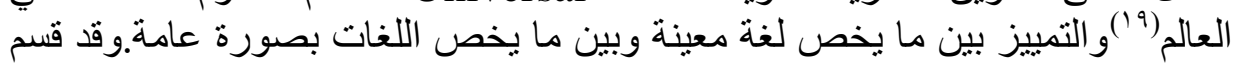

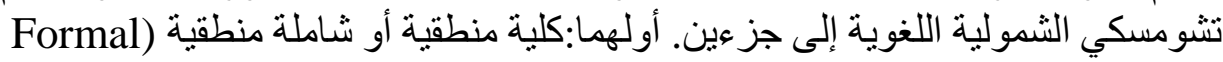

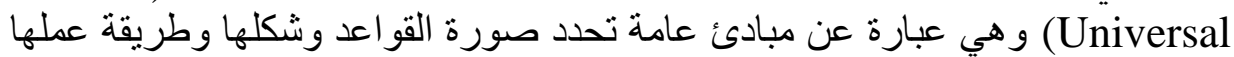

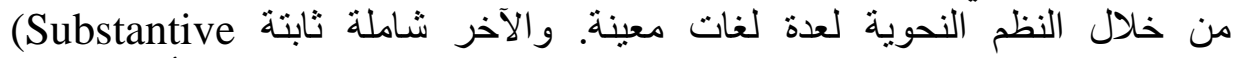
Universal)

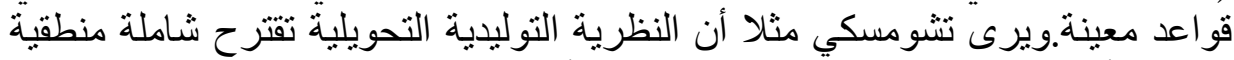
باعتبار أنواع القواعد في النحو، وعلى وعلى حين أنها تعتبر طبقا للنظرية اللغوية العامة. عناصر كلية ثابتة (ب)..

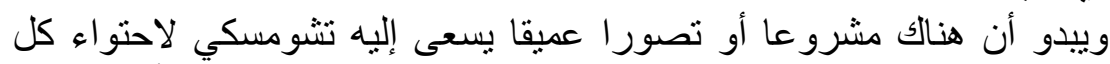

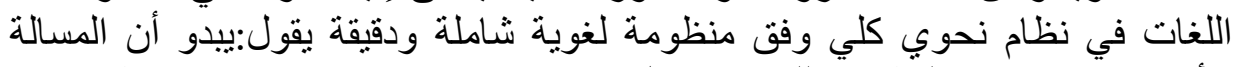

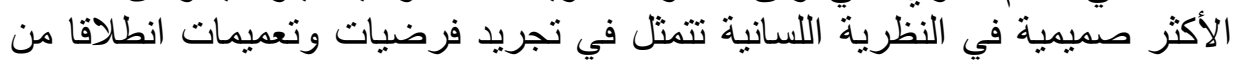

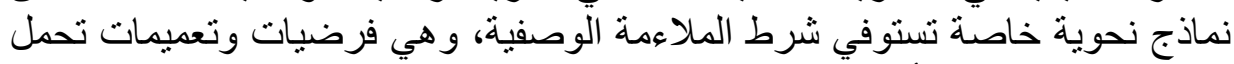

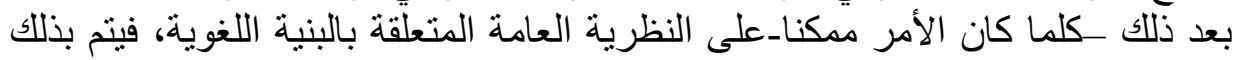

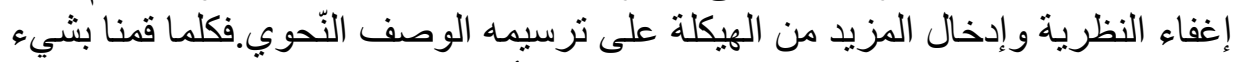

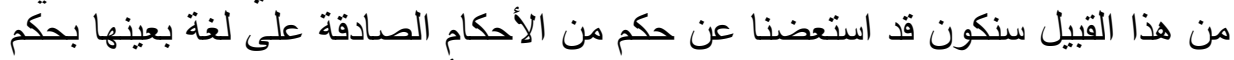

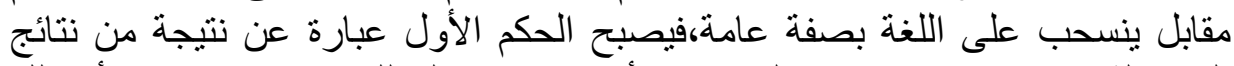

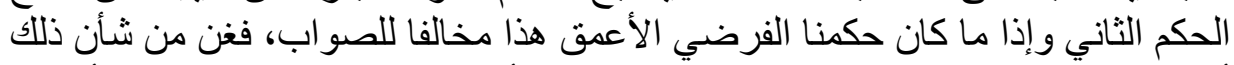

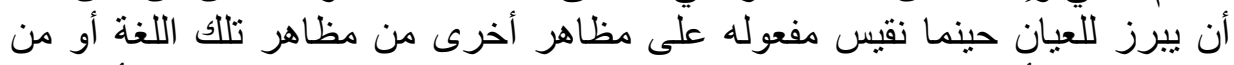

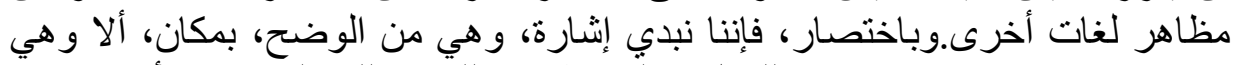

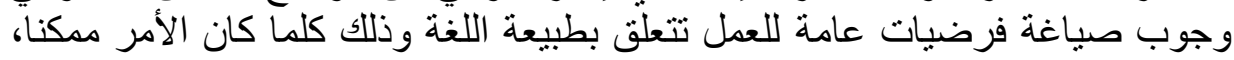

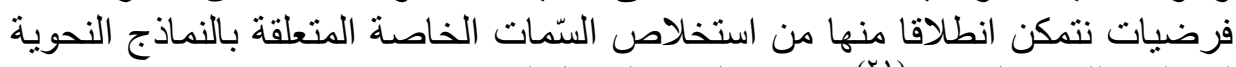

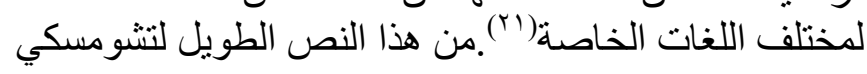

Rules can vary from language to language within constraints imposed by universal;but it is often assumed that

N- chomsky\&M.Halle,TheSound Pattern of English,P.4 - 19

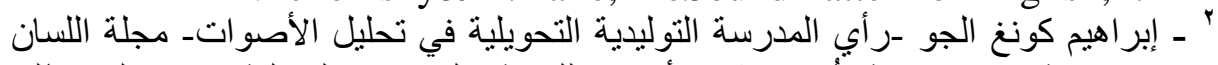

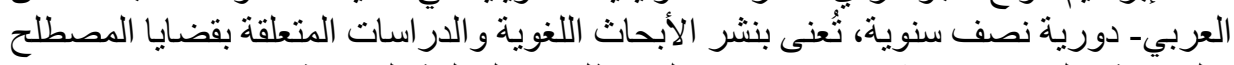

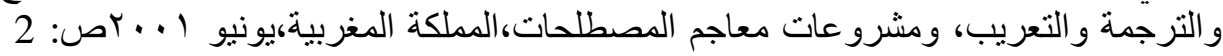
التمهيد.

N.Chomsky,Aspects de le théorie syntaxique,p.68 vo 
conditions on rules must be invariant.This assu;ption is somewhat arbitrary.There is no priori not to assume ${ }^{(22)}$ the opposite نتوصل إلى معرفة الهذف البعيد لنظريته، وهذا أدى ببعض اللغئل اللغويين

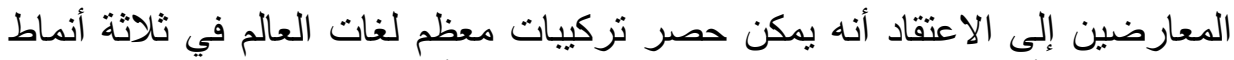

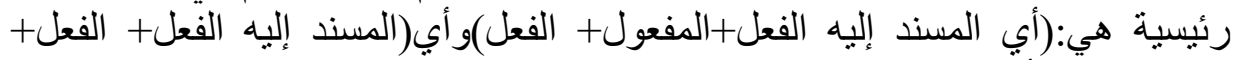

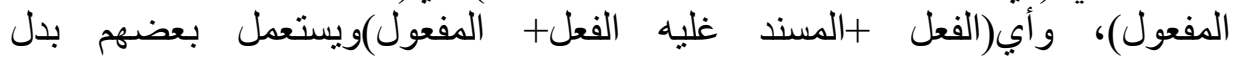

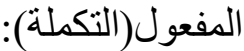

ويعطي هذا الجملة الفعلية أو التي فيها المسند(الفعل)هيمنة عالمية كما أن هذه

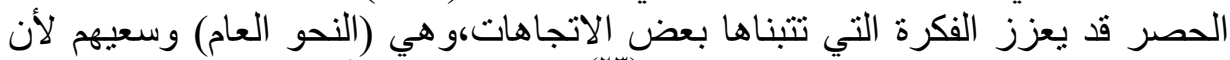

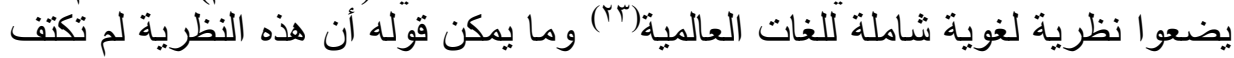

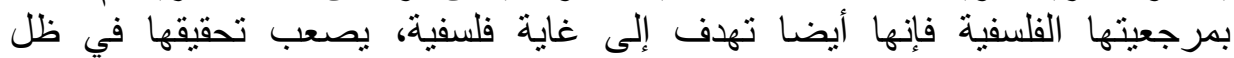

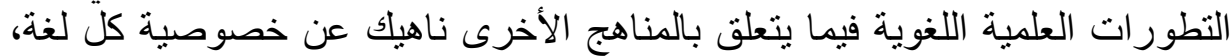

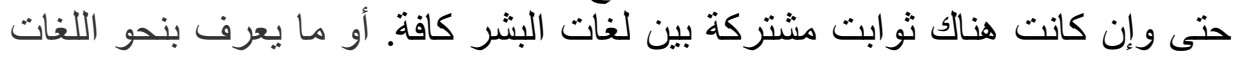

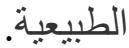

ـ ـالفرق بين اللغتين(العربية و الانجليزية) إن اللغة العربية هي لغنة النظّرية النحوية الخليلية، والانجليزية لغة النظرية النحوية

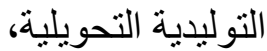
ولما كان الأمر كذلك فالمقارنة بينهما من حيث بعض الخصائص أمر واجب حتى يظهر

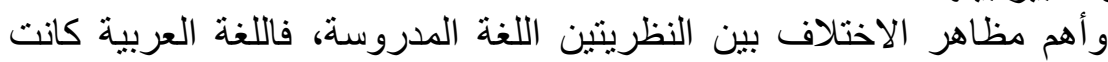

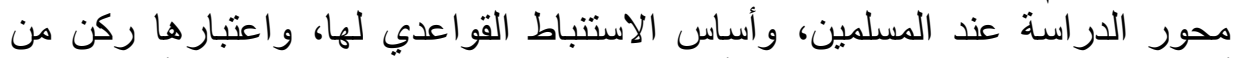

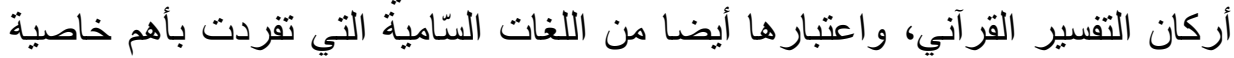

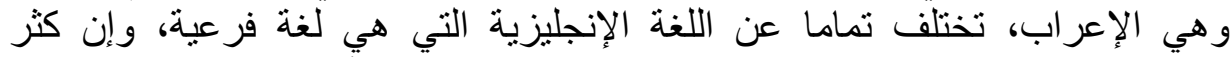

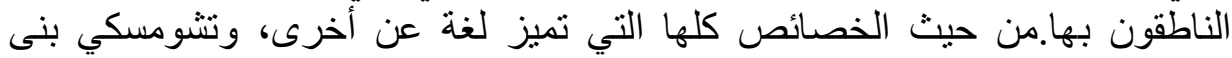
نظريته على هذه اللغة لذى نقاط الاختلاف كثيرة بيزهما.

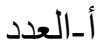

$$
\begin{aligned}
& \text { (لا يو جد مثنى ) } \\
& \text { (مفرد ومثنى وجمع) ) }
\end{aligned}
$$

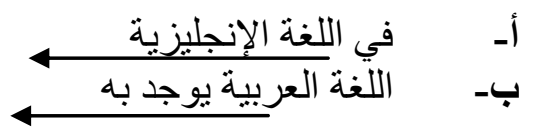

22 - N.Chomsky,On WH.Movement"in Formal Syntas.Wasow;Culicover and Akamajian eds.Ndw York;AcademicPress;1977,p.75 rr _حسن عبد الغني جواد الأسدي- مفهوم الجملة عند سيبويهـدار الكتب العلمية بيروت لـلبنان 


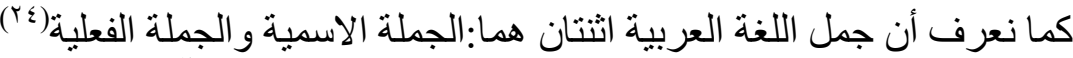
ب-التركيب

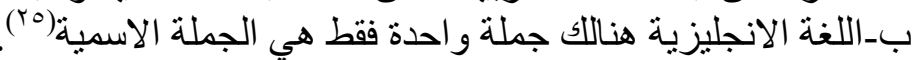
و هذا له تأثير حتى على مستوى تحليل الجمل، و إسقاط المفاهيم ولنظظر إلى هذه

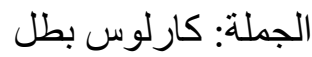
نلاحظ أن هذه الجملة اسمية ولكن قلنا أنه لا يوجد جملة اسمية في اللغة الانجليزية إذا كيف سنترجمها إلى اللغة الانجليزية؟ ولئه

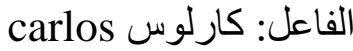

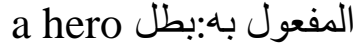
is, $\longrightarrow$ he, she, it للوصول إلى الفعل بإضافة اسم مفرد

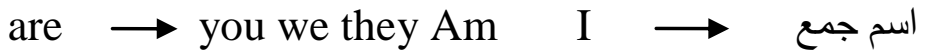
و الأفعال is,are,am معناها يكون وماضيها was, were بمعنى (كان)

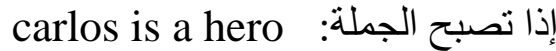

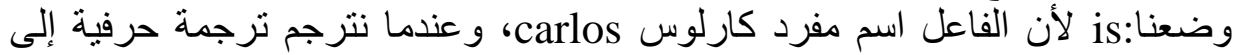

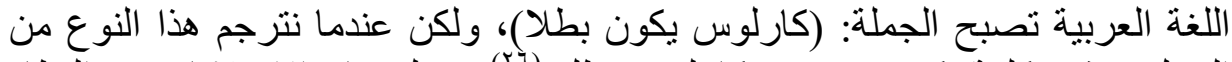

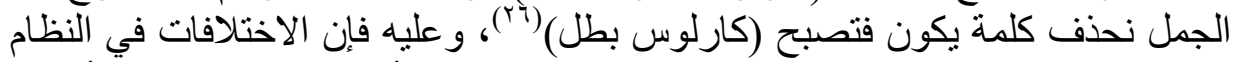

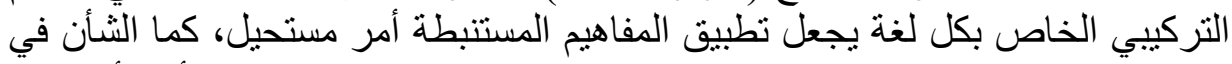

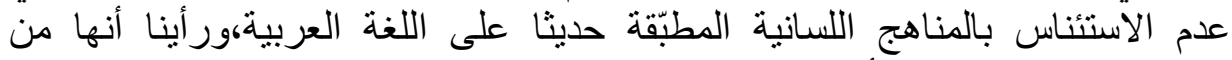
الإسقاطات الوهمية، و إن أفضت إلى إلى بعض النئ النتائج الجزئية الموجية. ج-مستوى جذر الكلمة. ـالعربية تعمل على المحافظة على الثلى الثكل البنائي الأصل للفظ(الحدث) المأخوذ من أحداث الأسماء(أسماء الفاعلين) في تحقيقاته المختلفة فيما مضى وفي الأني المضارع وفي

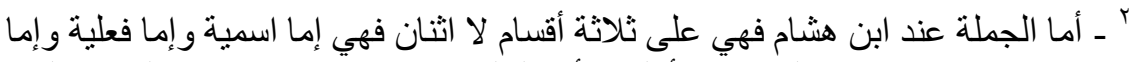

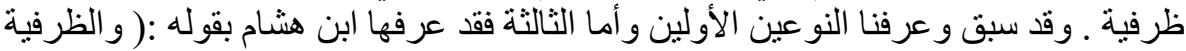

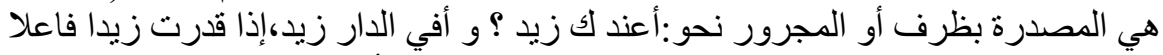

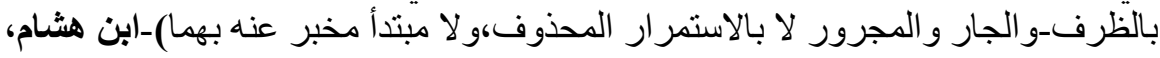
(المغني،ص: 9 ؛ ؛ )

25. Omar AL- Hourani -WWW.expressenglish.4t.com.Basics of English language. page 15

26- Omar AL- Hourani -WWW.expressenglish.4t.com.Basics of English language. page 15 
الأمر وهو شيء قد لا بتحقق في كثير من اللغات بمثل الصرامة التي في العربية

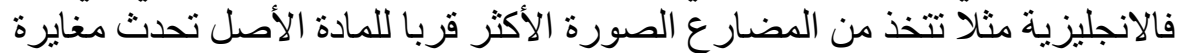

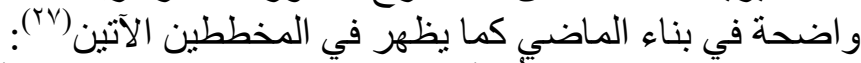

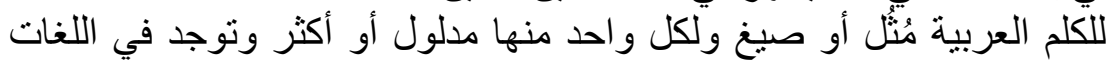

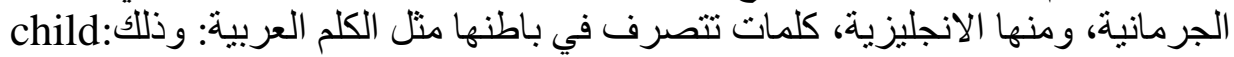

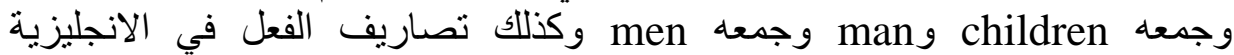

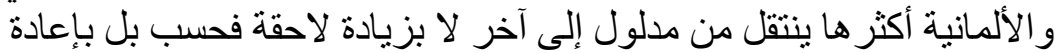

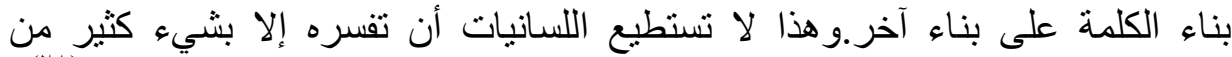

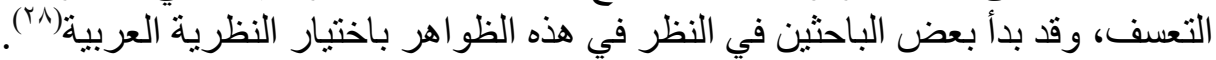

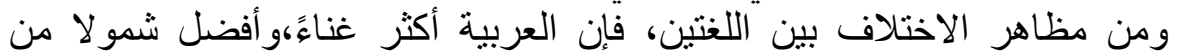
الانجليزية من جهة تخصيص العدد والنوع، فالتعبير عن المخاطب مثنلا في المذكر

you play foot

${ }^{\left({ }^{9}\right)}$ you are a her

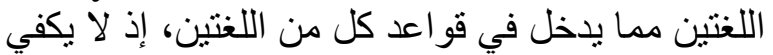

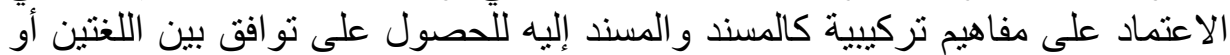

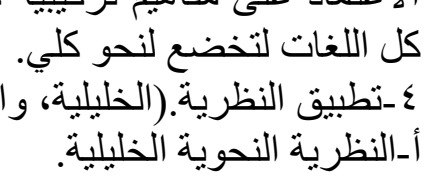

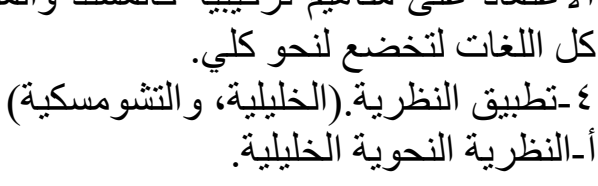

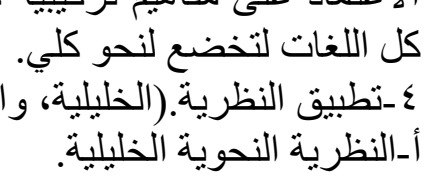

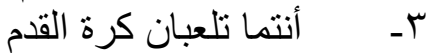
ball

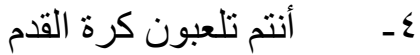

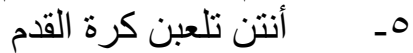

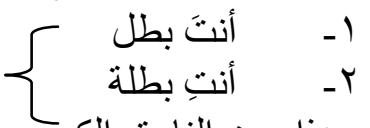

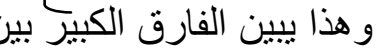

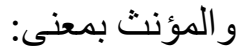

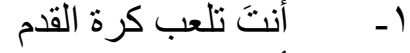

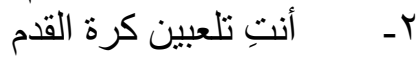

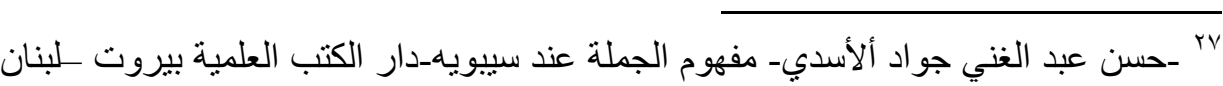

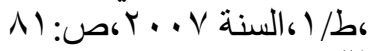

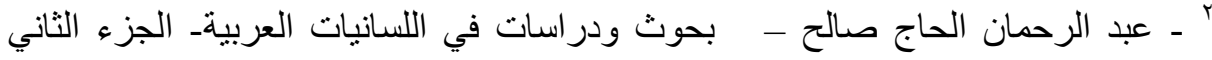
، Omar AL- Hourani -WWW.expressenglish.4t.com.Basics of English - ${ }^{r q}$ 


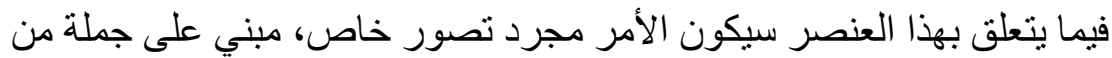

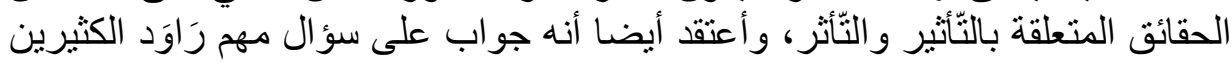

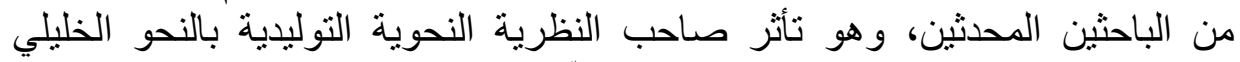

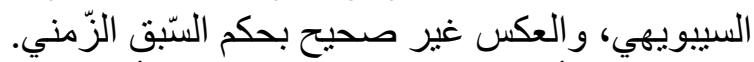

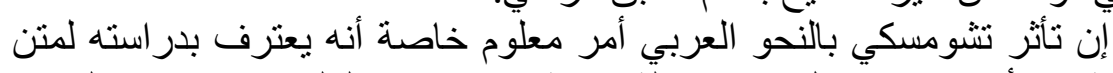

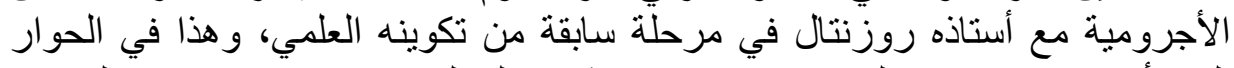

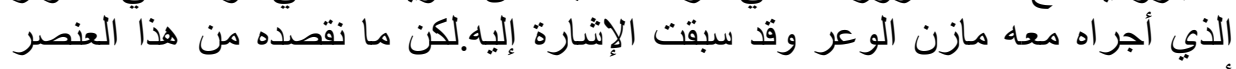
أمرين هما:

$$
\text { أ- - مل هل هل هلع نتو مسكي على كتاب سيبويه؟ }
$$

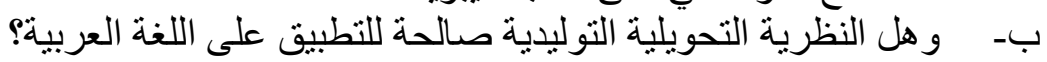

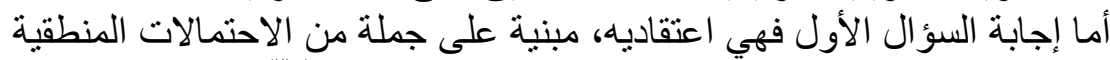

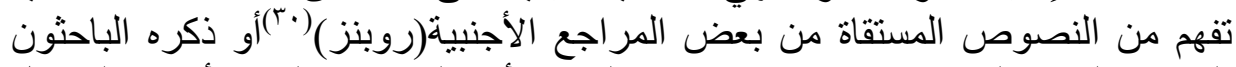

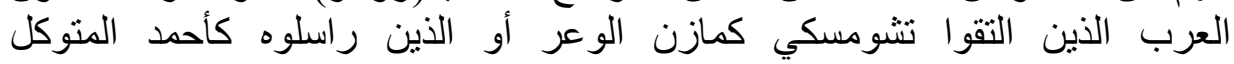

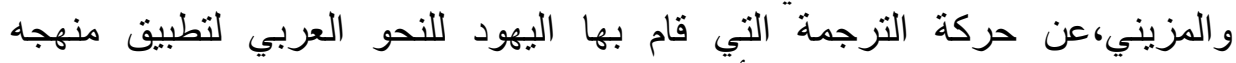

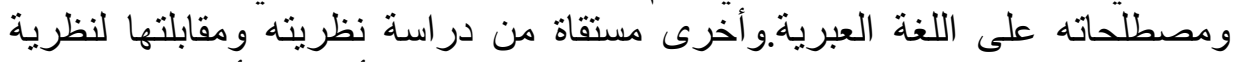

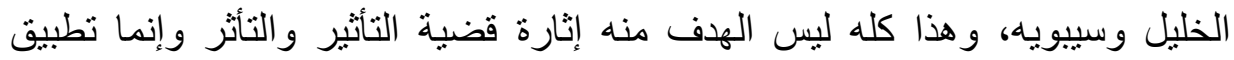
النظرية الخليلية على اللغة الانجليزية، وتطبيق النظرية التوليدية التحويلية على التئ العربية والنتائج المتوصل النئل إليها.

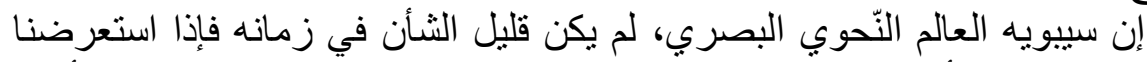

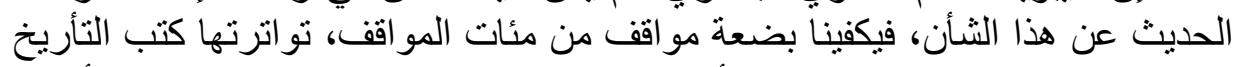

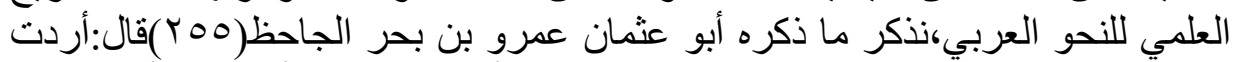

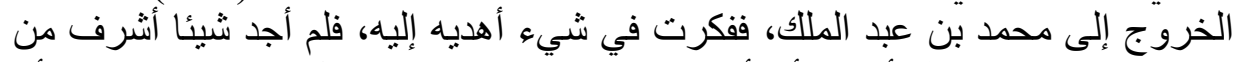

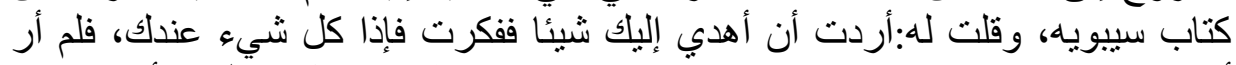

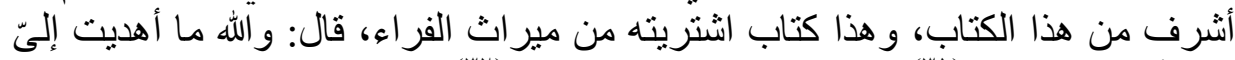

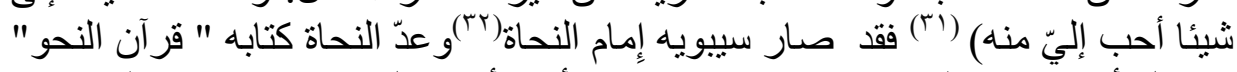

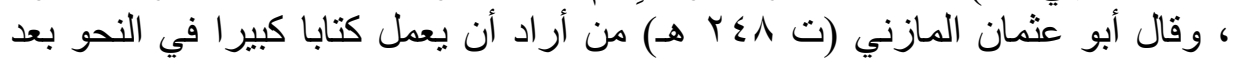

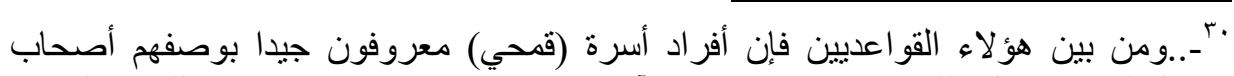

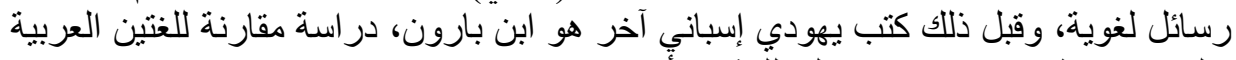

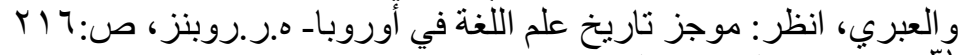

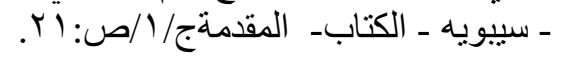

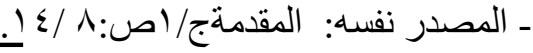




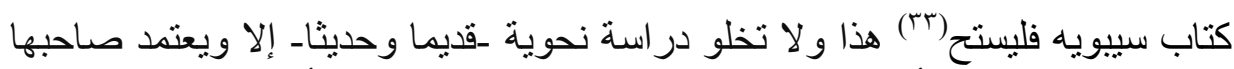

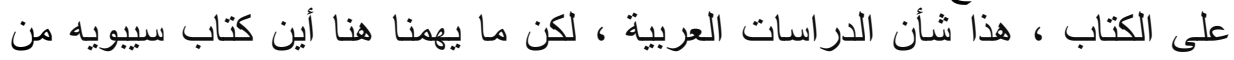

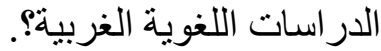
ذكر المؤرخون الغربيون أن تاثير البحوث غير الأوروبية كان كبيرا وله أثر في

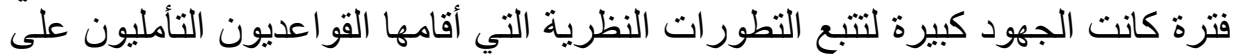

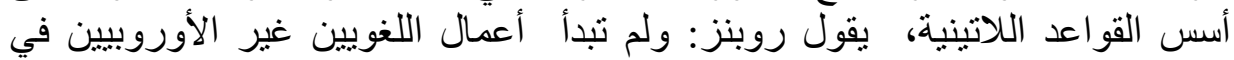

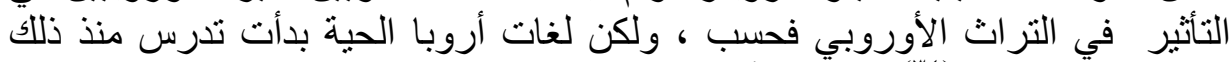

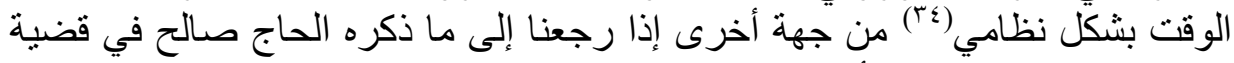

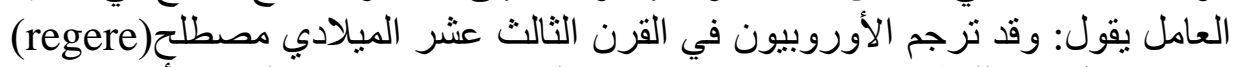

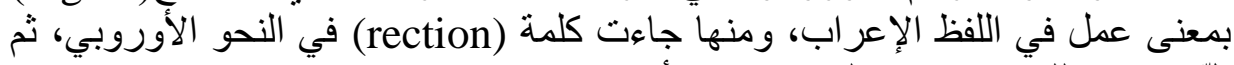

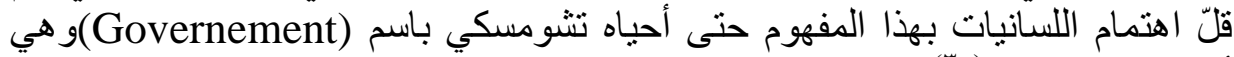

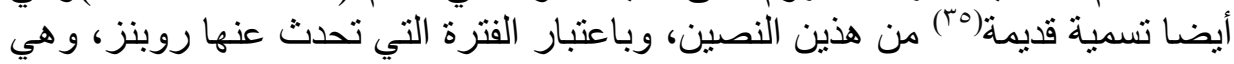

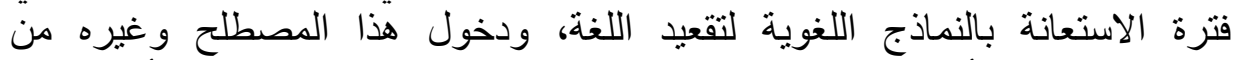

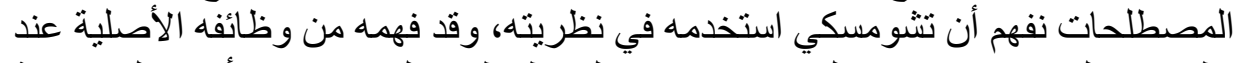

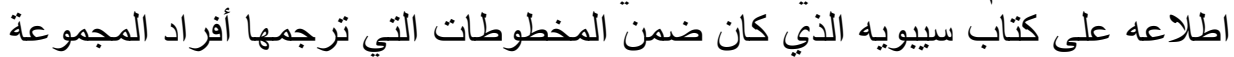

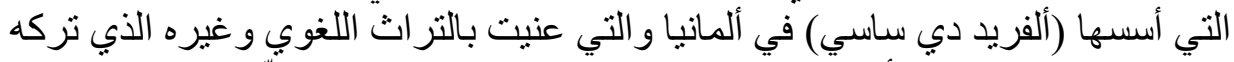

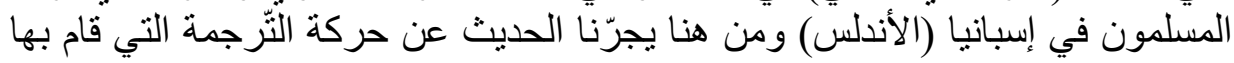

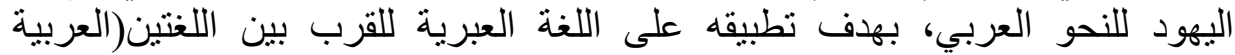

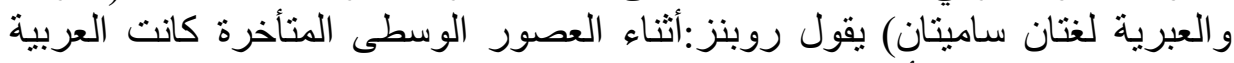

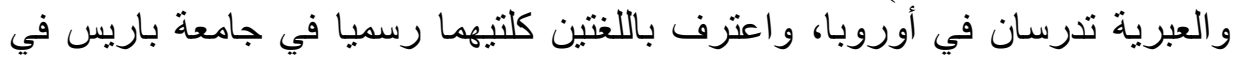

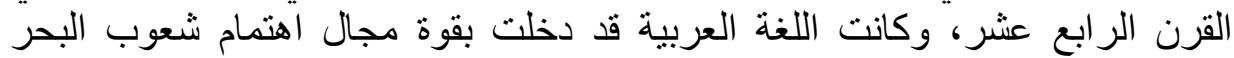

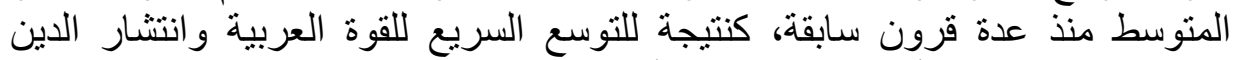

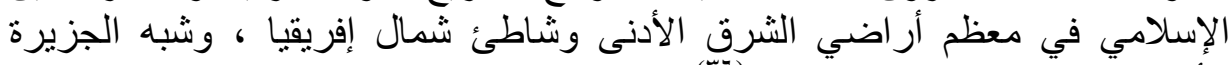

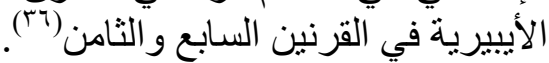

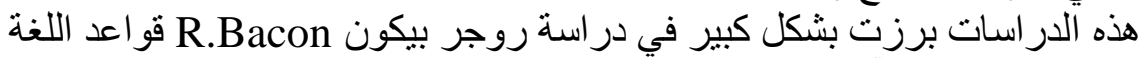

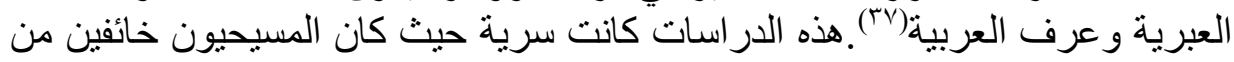

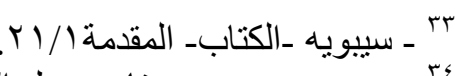

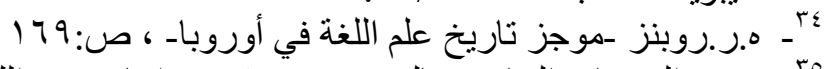

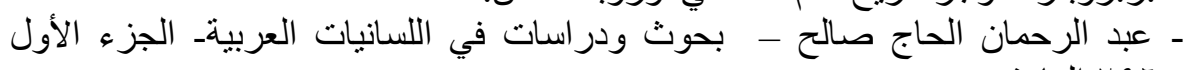

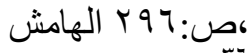

الم 179 $\Lambda$. 


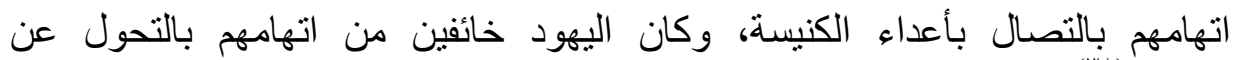

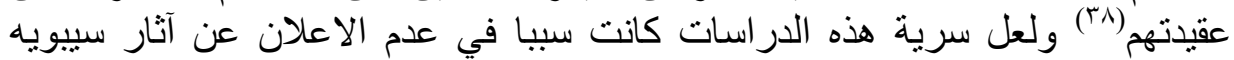

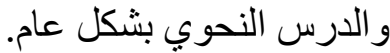

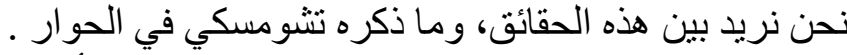

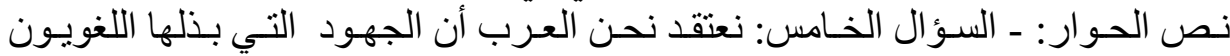

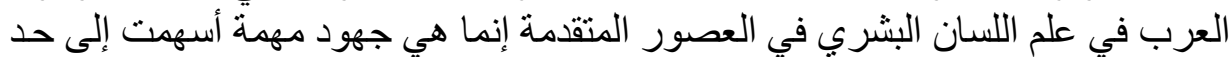
كبير في بناء علم اللسان الحديث linguistics ما هي آر اؤك حول هذه القضية القيّ؟

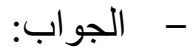

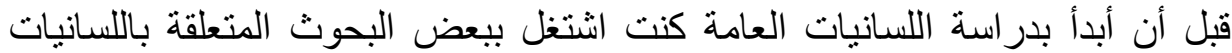

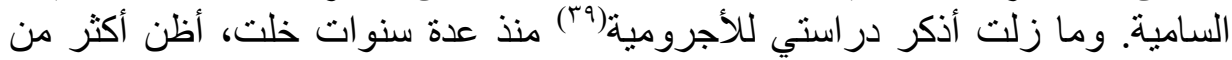

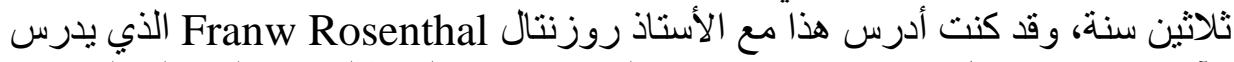

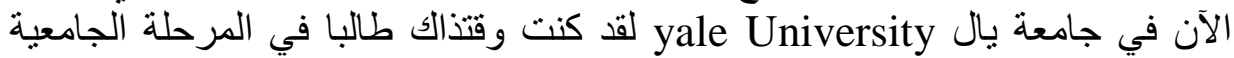

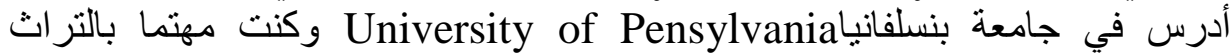

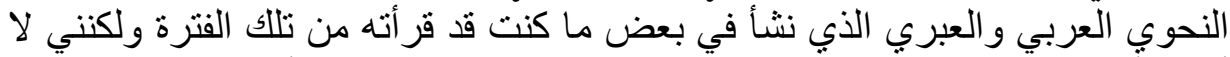

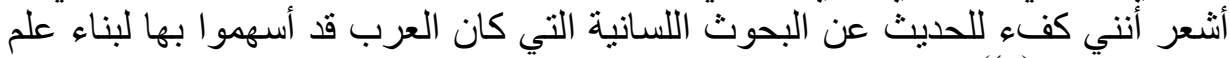

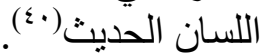

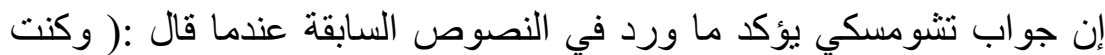

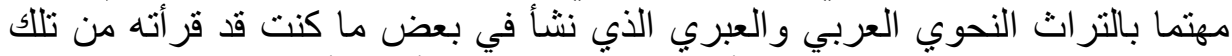

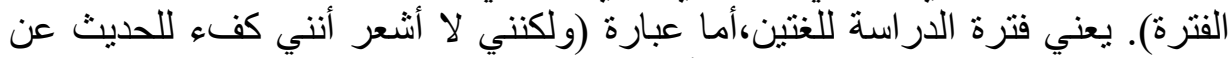

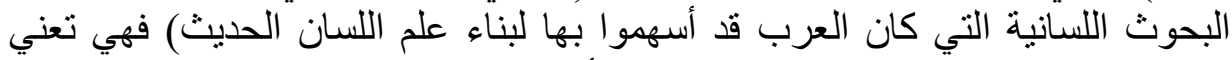

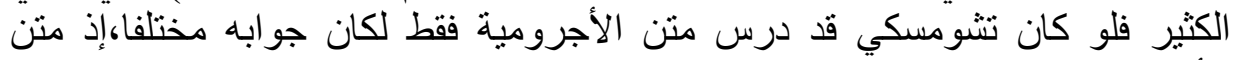

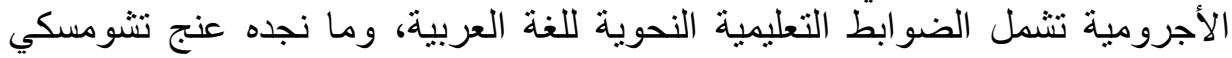

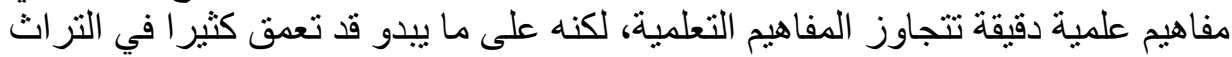

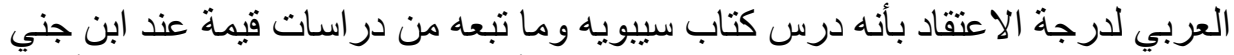
والجرجاني والرضي..يقول جاسم: فيجب علينا ألا نغفل دور اللغة العبرية وتأثر ها

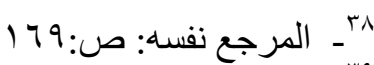
ـالأجرومية: هو كتاب مختصر مشهور في النحو العربي لمؤلفه ابن آجروم(القرن الثامن

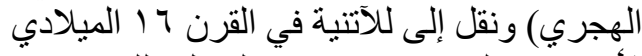

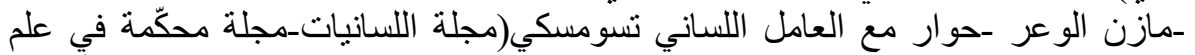

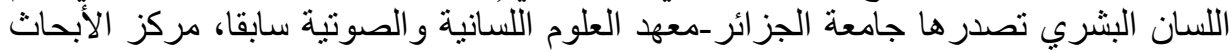

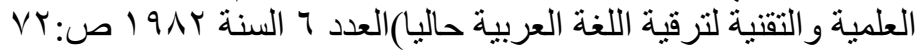


بالنحو العربي ومعرفة تشومسكي لها معرفة تامة؛ فهي الواسطة بين العربية واللغات

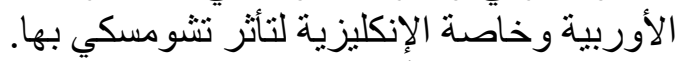

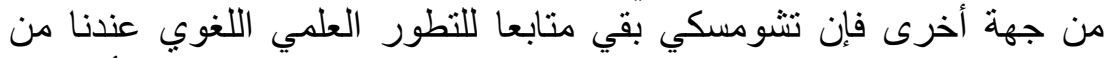

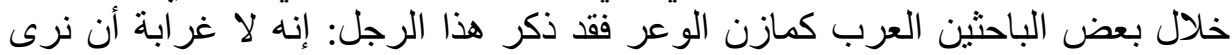

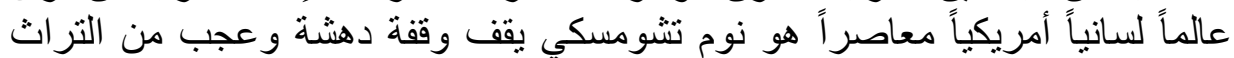

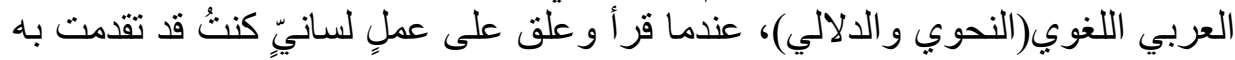

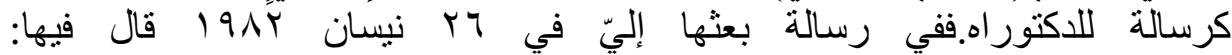

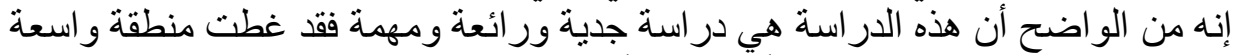

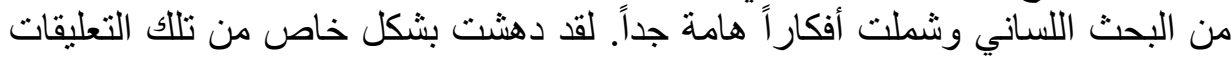

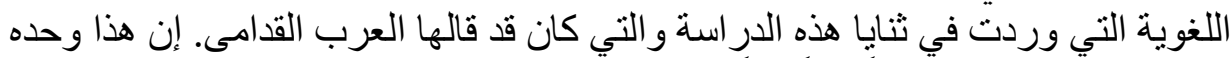

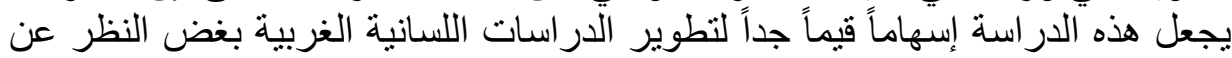

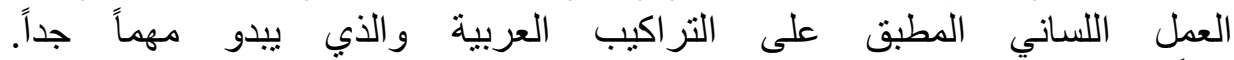

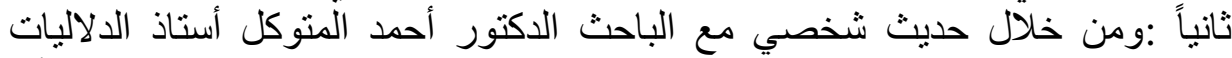

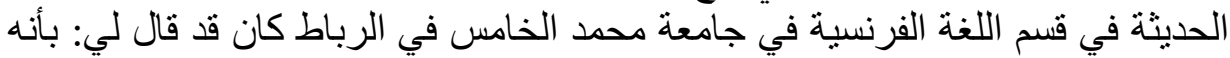

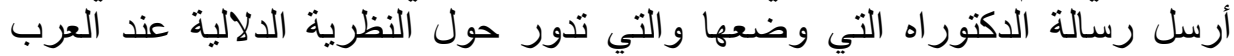

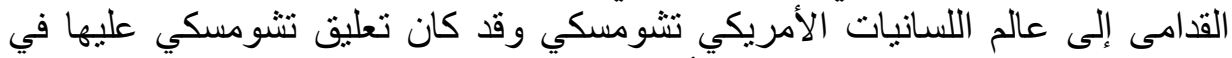

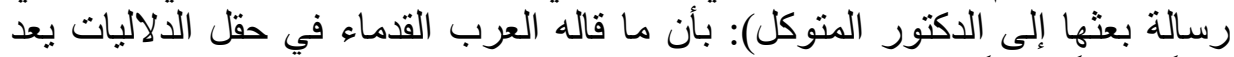

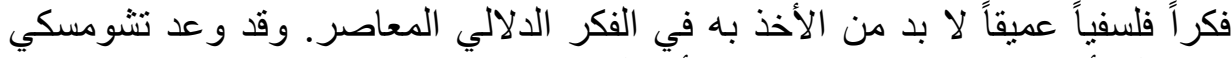

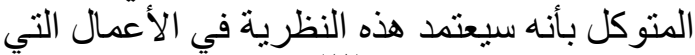

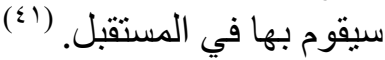
ب-نظرية النحو التوليدي التحويلي.

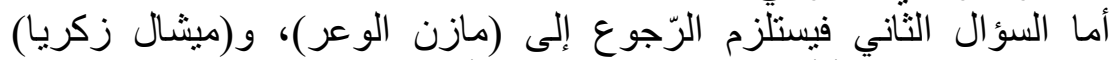

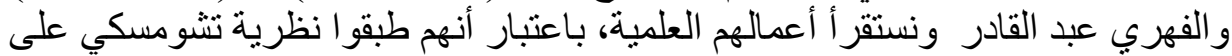

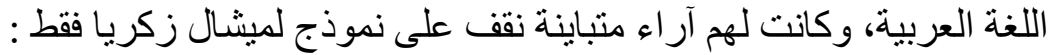

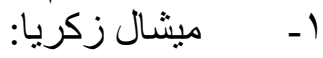

اء - جاسم علي جاسم ـتأثير النحو العربي في نظرية نشومسكي - معهد تعليم اللغة العربية

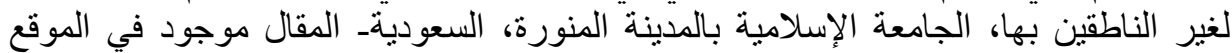
الإلكتروني لصاحبه jassem@hotmail.com، أنظر أيضا نشومسكي في عيد ميلاده

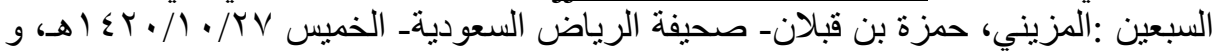

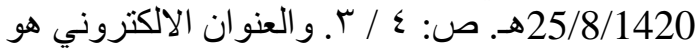
و http://www.hmozainy.jeeran.com/tshomesky4.htm .$\vee$ : 
من أبرز المهتمين بنظرية تثومسكي ميشال زكريا، وهو و إن كان مهتما بهذه إنها

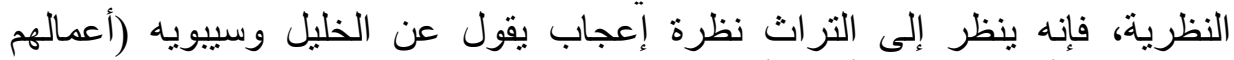

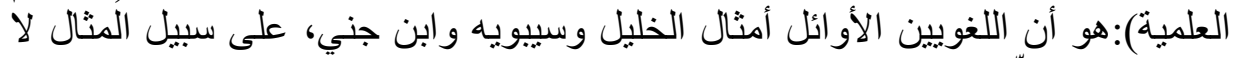

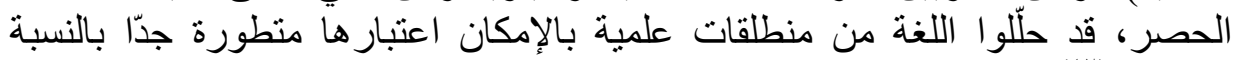

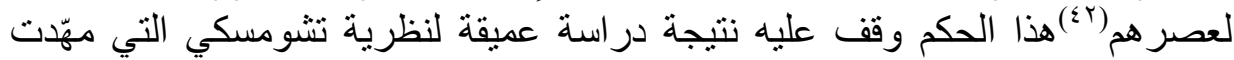

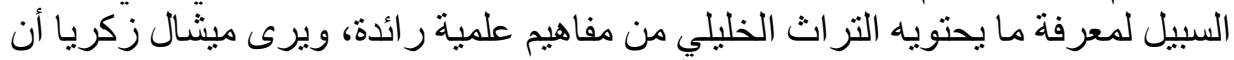

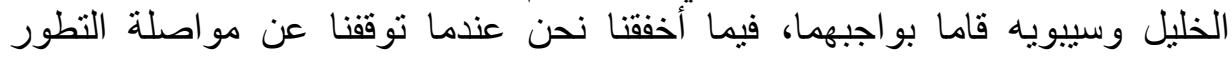

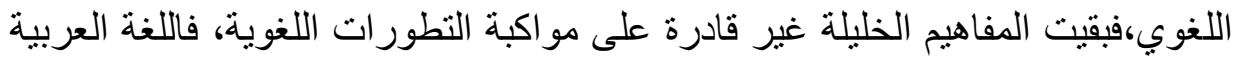

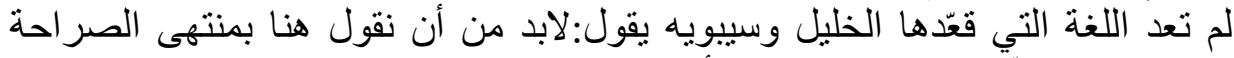

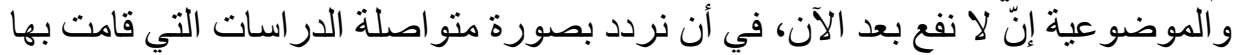

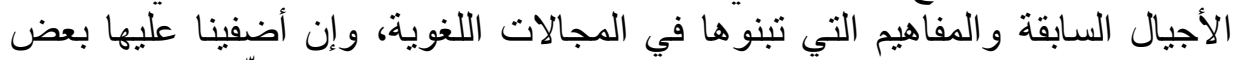

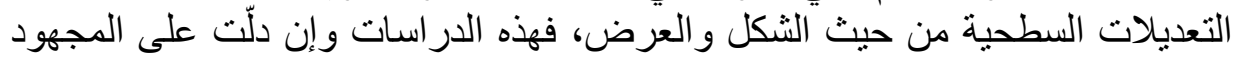

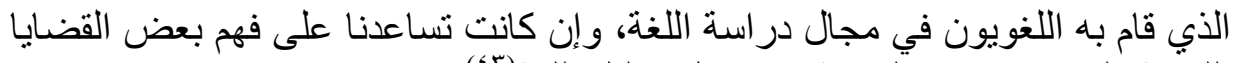

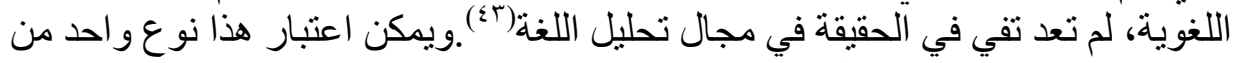

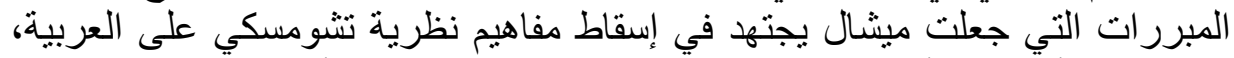

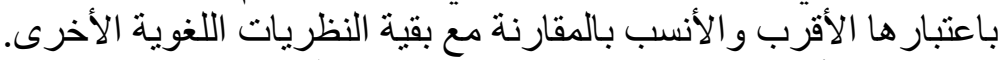

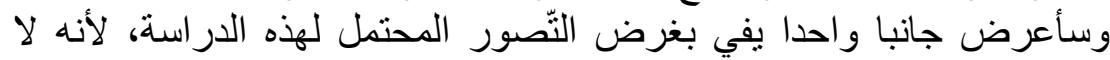

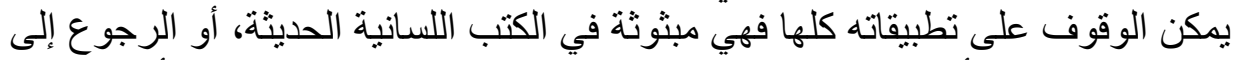

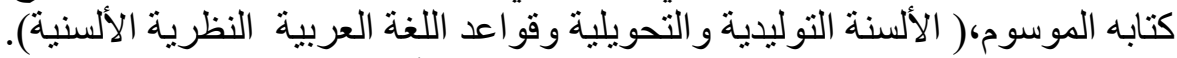

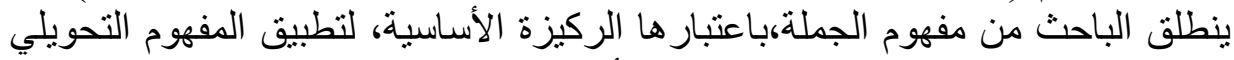

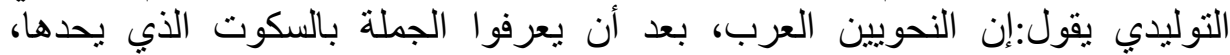

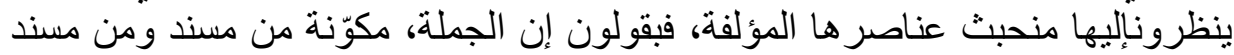

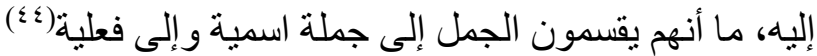

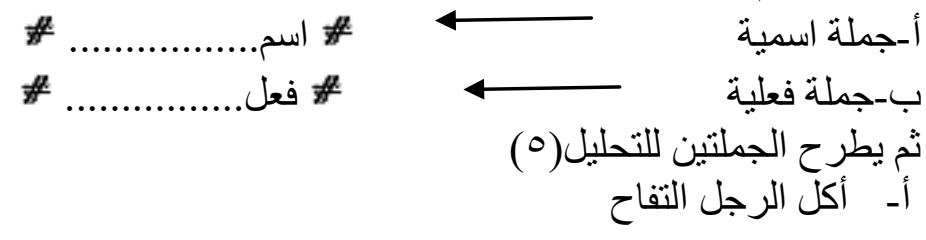

rأـ ميثال زكريا ـ الألسنة التوليدية والنحويلية وقو اعد اللغة العربية النظرية الألسنيةـ ، ص

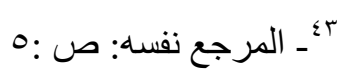

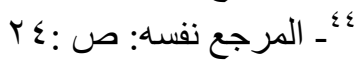


يقول:من الواضح أن الجملتين(هـأ)و(ه-ب) تحتويان على العناصر ذاتها

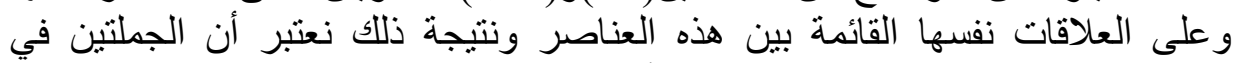

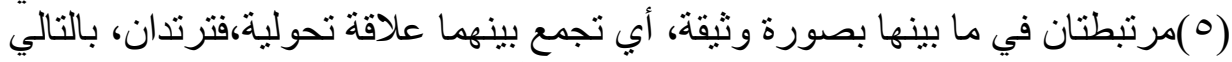

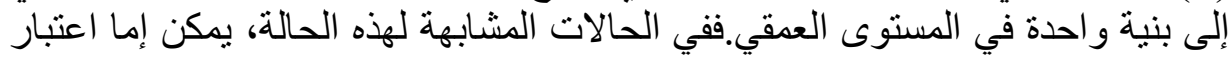

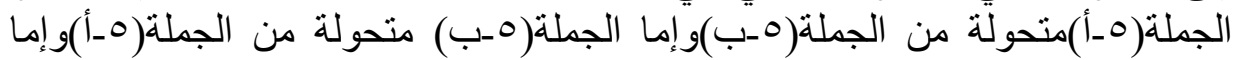

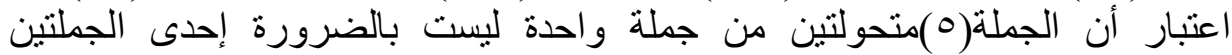

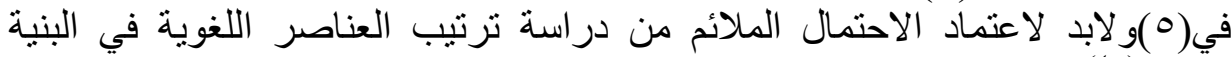

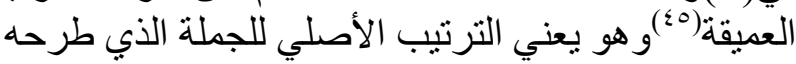

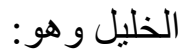

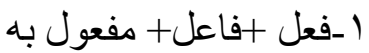

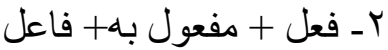

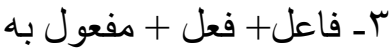

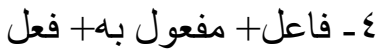

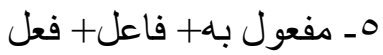

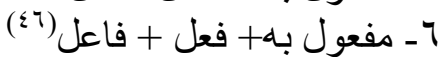

ويقابل في الترتيب الهيكلي للجملة بجملة ذات دلالة غير مستقرة في بعض التض التر اكيب ومستقرة في البعض الآخر

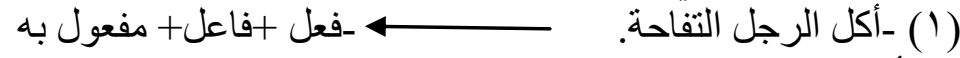
(r) (ك)

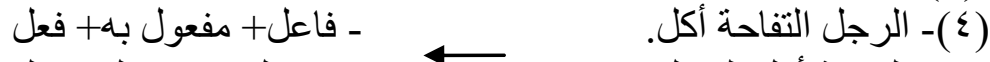
ऍ

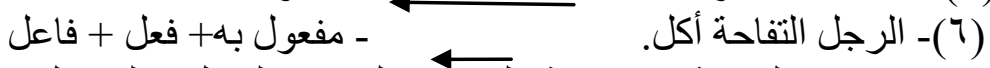

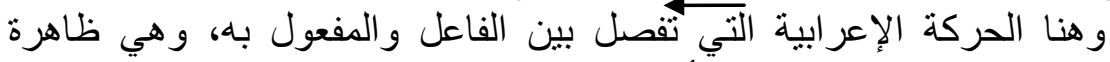
منطقيا،و العلامة تعني الجمل غير الأصولية التي تدخل في نظام اللغة، و هناك جملتان التان

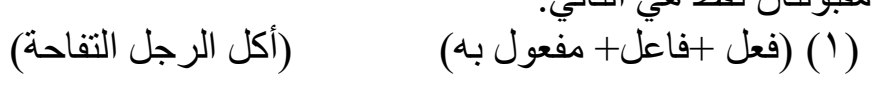

•ـــ ميثال زكريا ـ الألسنة النوليدية والنحويلية وقو اعد اللغة العربية النظرية الألسنيةـ ، ص

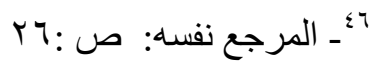




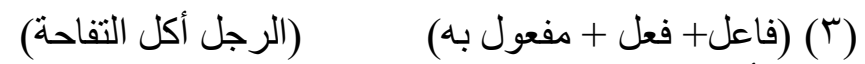

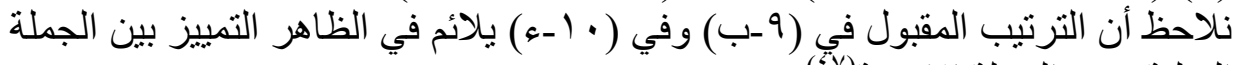

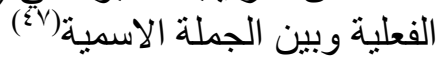

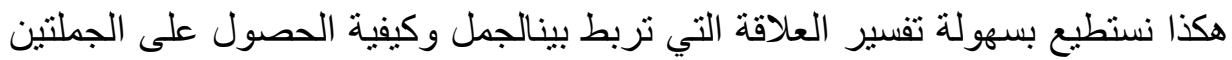

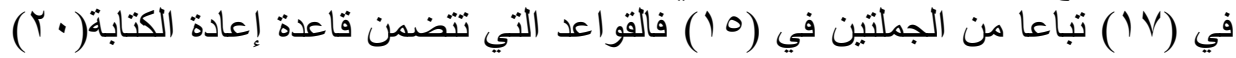

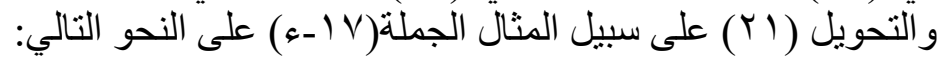

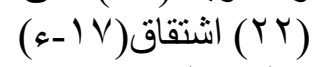

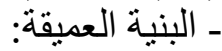

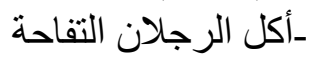

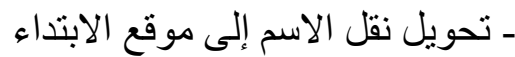

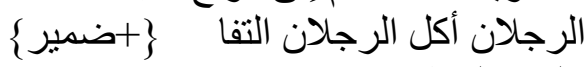

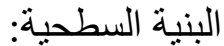
ـ الرجلان أكلا التفاحة.

تعثبر من التر اكيب غير الأصولية مع أنها تدخل في نظام اللغة العربية، فنقول مثلا

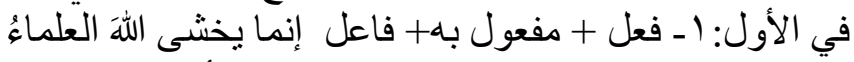

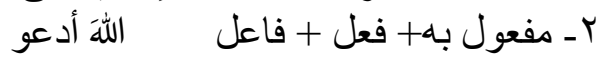

فميثال زكريا انطلق من احتمال وانتقاق تركيبي دون النظر إلى إلى مرونة اللغة التئة العربية في قضايا التقديم والتأخير والمقاصد الدلالية من ذللك، والرجون النطع إلى الددونة كما

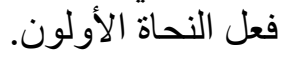

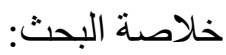

وما نستخلصه هو أن العربية غير الانجليزية فهي لا تدرك إلا بآليات خاصة الاصنة

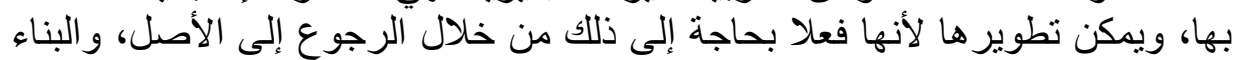

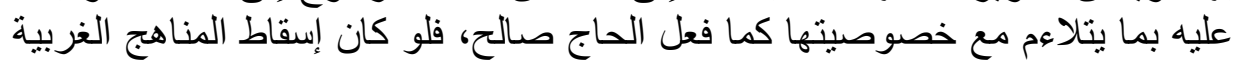

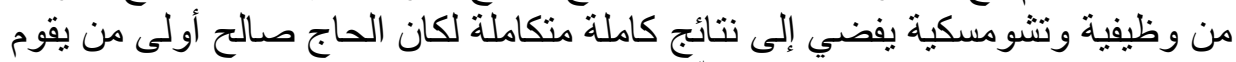

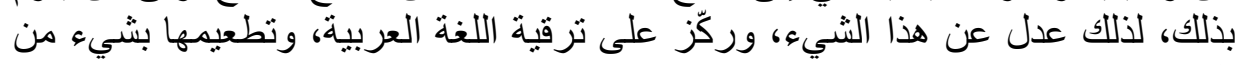

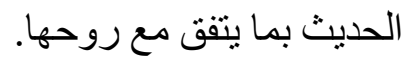

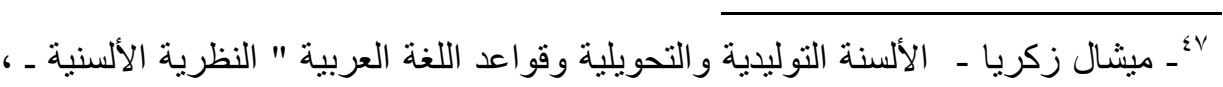
rv: ص 10 


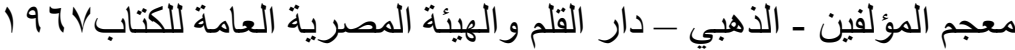

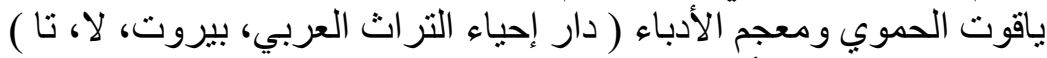

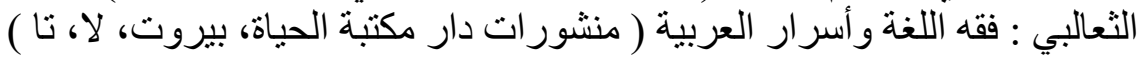

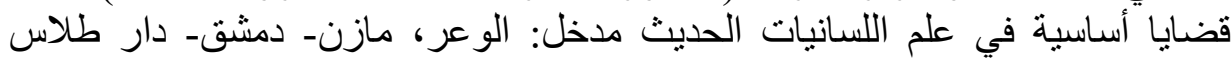

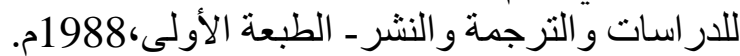

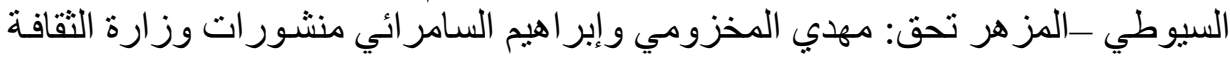

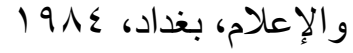
عبد الرحمان الحاج صالح ـ ـ السماع اللغوي العلمي عند العرب ومفهوم الفصاحةــ

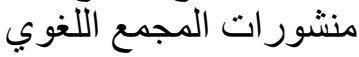
عبد الرحمان الحاج صالح - بحوث ودراسات في اللسانيات العربيةـ منشورات المجمع

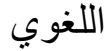
محمد عماد الدين إسماعيل ـالأطفال مرآة المجتمع- علم المعرفة سلسلة كتب ثقافية

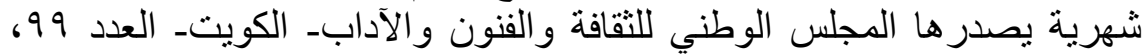
يناير السنة. 199 محمد عماد الدين إسماعيل ـالأطفال مرآة المجتمع- علم المعرفة سلسلة كتب ثقافية

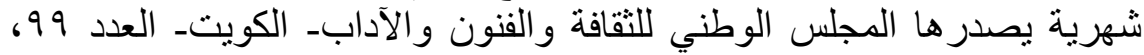

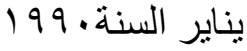
سبب وضع علم العربية ، السيوطي ، تحق : مروان العطية ، دار الهجرة ، دمشق ، ط :

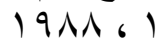
إبراهيم كونغ الجو -رأي المدرسة التوليدية التحويلية في تحليل الأصواتــ مجلة اللسان

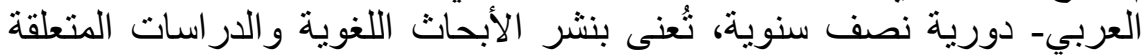

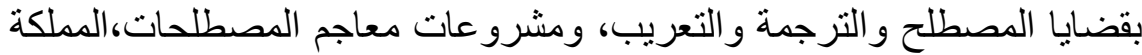

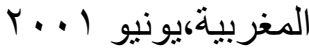
حسن عبد الغني جو اد الأسدي- مفهوم الجملة عند سييويهـدار الكتب العلمية بيروت ـ

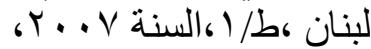
ابن هشام -مغني اللبيب- تحق مازن المبارك وآخر ، بيروت : دار الفكر ، 1910 ، ط : 1

ميشال زكريا ـ الألسنة التوليدية والتحويلية وقواعد اللغة العربية النظرية الألسنيةــ الكتاب ، سيبويه ، تحق : عبد السلام هارون ، دار القلم و الهيئة الدصرية العالية العامة للكتاب 
ر.ه.روبنز - موجز تاريخ علم اللغة في الغرب- سلسلة كتب شهرية يصدر ها المجلس

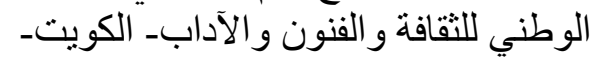

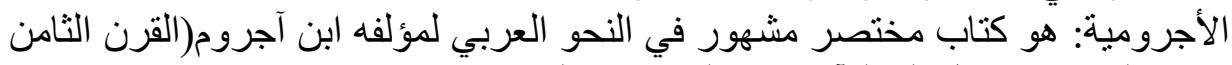

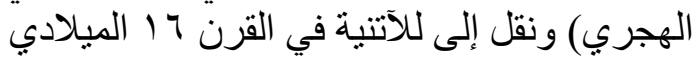

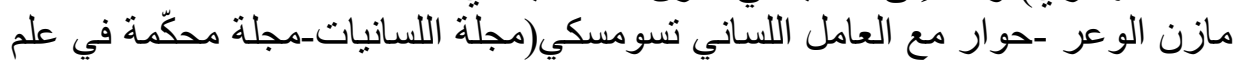

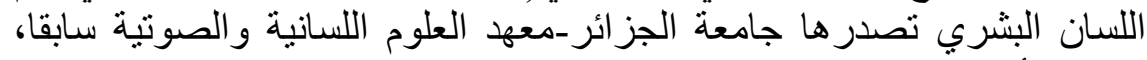

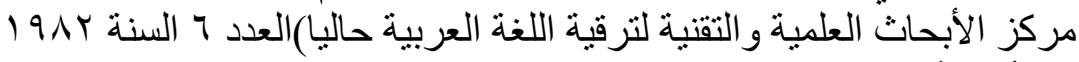

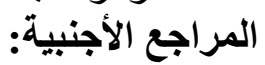

chomsky\&M.Halle,TheSound Pattern of English,P.4- N

N.Chomsky,Aspects de le théorie syntaxique,p.68

N.Chomsky,On WH.Movement"in Formal Syntas. Wasow; Culicover and Akamajian eds.Ndw York;AcademicPress;1977 ,p.75

ـ محمّد كثثّاش-مصية: المصلح النحو العربي بين الأصل المادي والتطور الدلالي ـمجلة

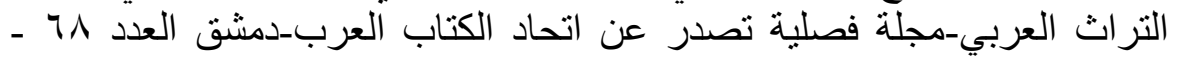

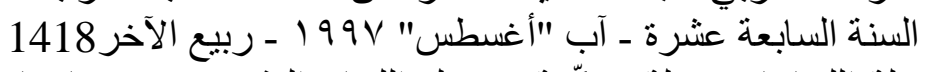

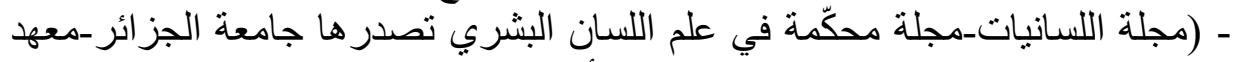

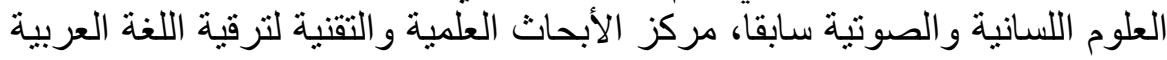

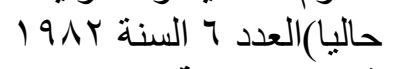
المواقع الإكترونية:

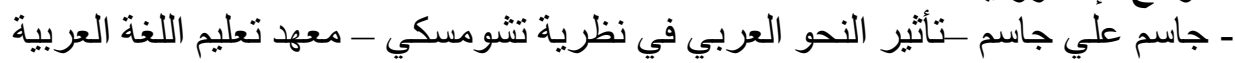

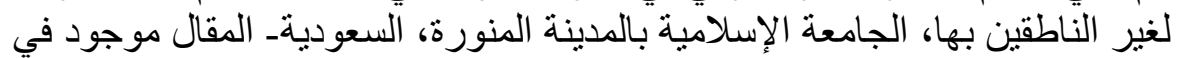

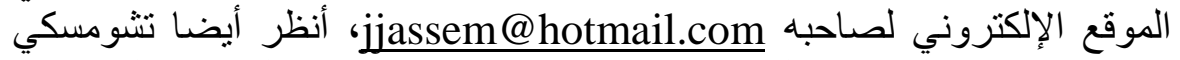

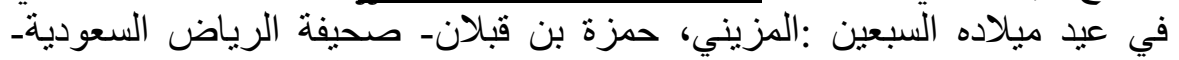

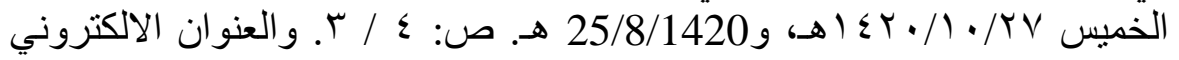

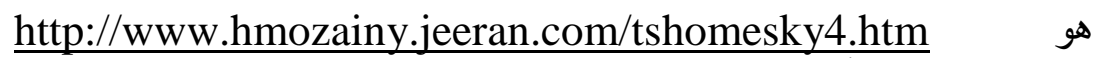
- جاسم علي جاسم -تأثير النحو العربي في نظرية تشومسكي - معهد تعليم اللغة العربية

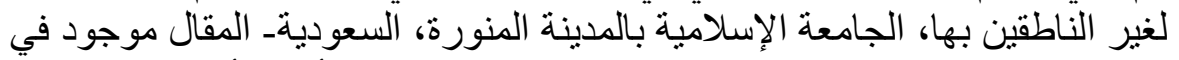

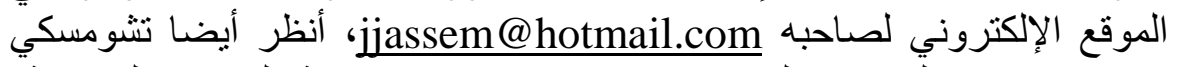
في عيد ميلاده السبعين :المزيني، حمزة بن قبلان- صحيفة الرياض السعودية- 
لـ ـ عبدالفادر بنه النواني الاختلاف بين النظرية التحوية العربية ونظرية ...

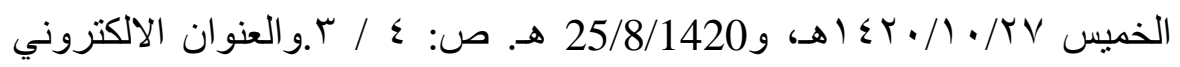
http://www.hmozainy.jeeran.com/tshomesky2.htm هو 